\title{
THE POTENTIAL FOR ENERGY EFFICIENCY AND RENEWABLE ENERGY IN NORTH CAROLINA
}

\section{April 2003}

Prepared by

S. W. Hadley 


\title{
DOCUMENT AVAILABILITY
}

Reports produced after January 1, 1996, are generally available free via the U.S. Department of Energy (DOE) Information Bridge:

Web site: http://www.osti.gov/bridge

Reports produced before January 1, 1996, may be purchased by members of the public from the following source:

\author{
National Technical Information Service \\ 5285 Port Royal Road \\ Springfield, VA 22161 \\ Telephone: 703-605-6000 (1-800-553-6847) \\ TDD: $703-487-4639$ \\ Fax: 703-605-6900 \\ E-mail: info@ntis.fedworld.gov \\ Web site: http://www.ntis.gov/support/ordernowabout.htm
}

Reports are available to DOE employees, DOE contractors, Energy Technology Data Exchange (ETDE) representatives, and International Nuclear Information System (INIS) representatives from the following source:

Office of Scientific and Technical Information

P.O. Box 62

Oak Ridge, TN 37831

Telephone: 865-576-8401

Fax: 865-576-5728

E-mail: reports@adonis.osti.gov

Web site: http://www.osti.gov/contact.html

This report was prepared as an account of work sponsored by an agency of the United States Government. Neither the United States government nor any agency thereof, nor any of their employees, makes any warranty, express or implied, or assumes any legal liability or responsibility for the accuracy, completeness, or usefulness of any information, apparatus, product, or process disclosed, or represents that its use would not infringe privately owned rights. Reference herein to any specific commercial product, process, or service by trade name, trademark, manufacturer, or otherwise, does not necessarily constitute or imply its endorsement, recommendation, or favoring by the United States Government or any agency thereof. The views and opinions of authors expressed herein do not necessarily state or reflect those of the United States Government or any agency thereof. 


\title{
THE POTENTIAL FOR ENERGY EFFICIENCY AND RENEWABLE ENERGY IN NORTH CAROLINA
}

S. W. Hadley

April 2003

\author{
Coordinated with \\ The North Carolina Solar Energy Center \\ NC State University \\ Industrial Extension Service \\ Campus Box 7902 \\ Raleigh, NC 27695 \\ OAK RIDGE NATIONAL LABORATORY \\ Oak Ridge, Tennessee 37831 \\ managed by \\ UT-BATTELLE, LLC \\ for the \\ U.S. DEPARTMENT OF ENERGY \\ under contract No. DE-AC05-00OR22725
}





\section{CONTENTS}

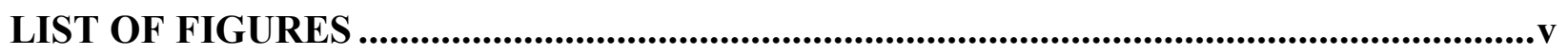

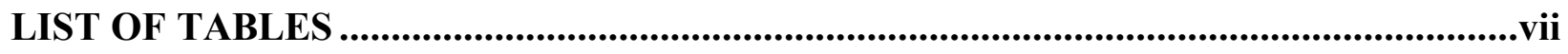

ACRONYMS ...............................................................................................................ix

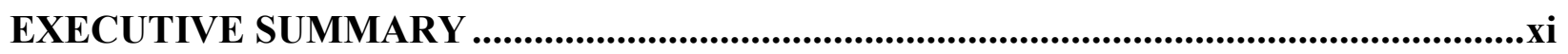

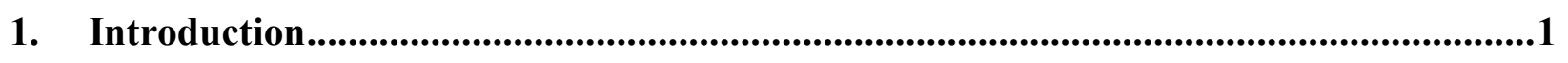

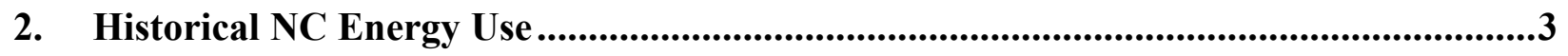

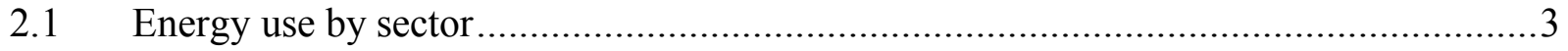

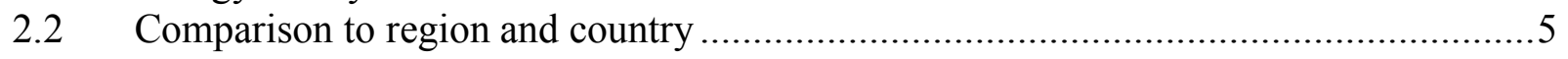

3. Economic Modeling with NEMS.........................................................................7

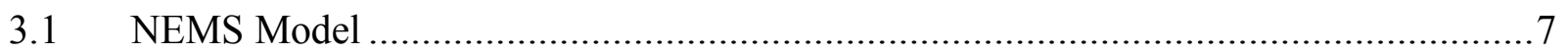

3.1.1 Residential Analysis in NEMS ............................................................. 8

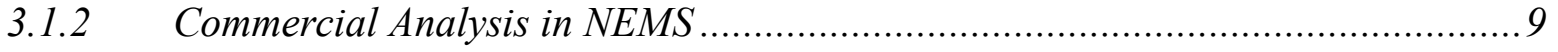

3.1.3 Renewables modeling in NEMS.............................................................. 10

3.2 Annual Energy Outlook 2003 ...................................................................... 11

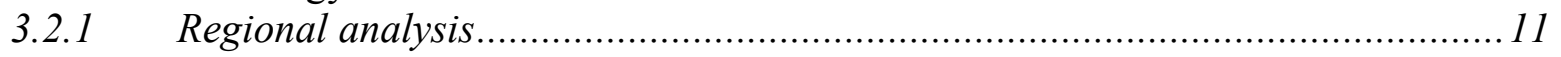

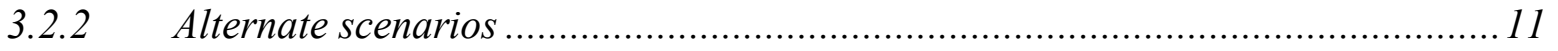

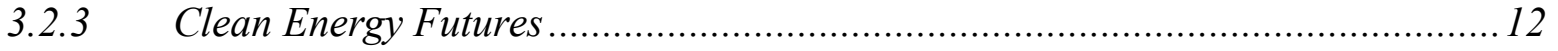

4. Residential Energy Analysis ....................................................................................15

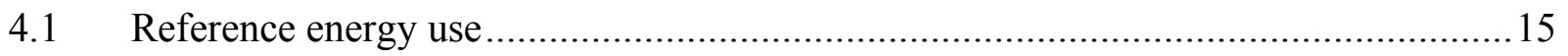

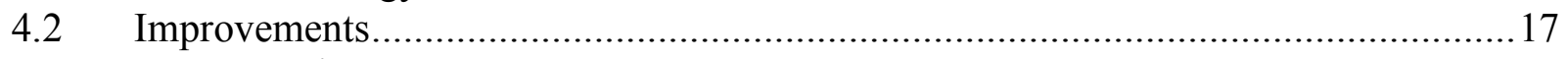

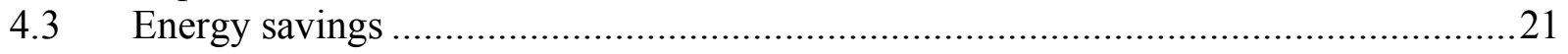

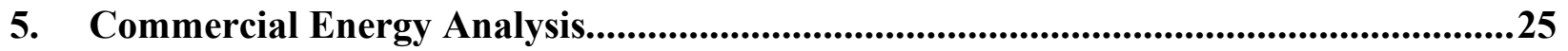

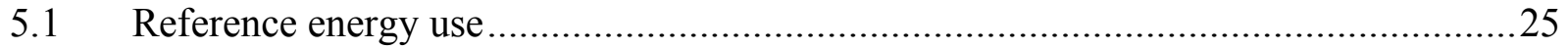

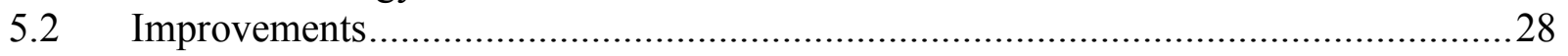

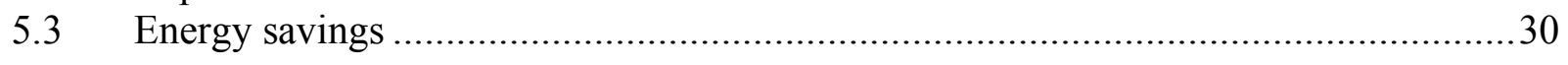

6. Renewable Energy Analysis ...................................................................................33

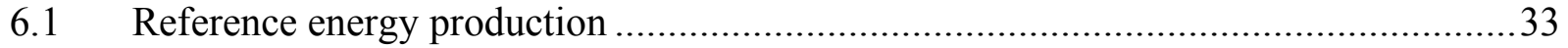

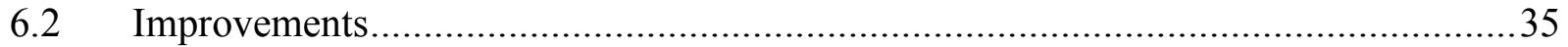

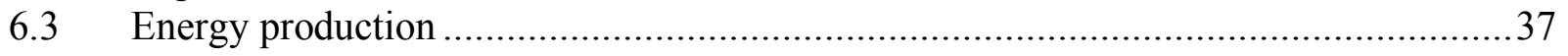

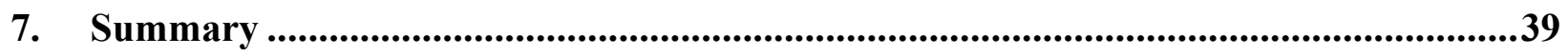

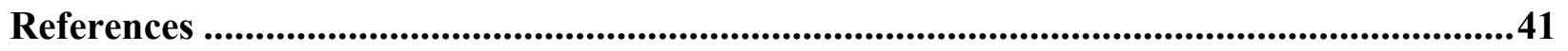





\section{LIST OF FIGURES}

Figure 1. Primary energy use within North Carolina, 1960-1999 from SEDS .........................3

Figure 2. 1999 energy use in North Carolina ..............................................................

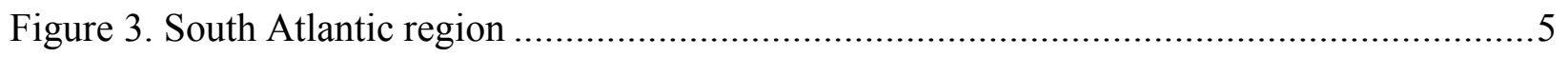

Figure 4. National Energy Modeling System Integration ............................................. 8

Figure 5. Clean Energy Futures Study national savings amounts........................................ 13

Figure 6. North Carolina residential electrical end-use in Base scenario ............................... 15

Figure 7. Residential energy prices for the South Atlantic region ........................................ 17

Figure 8. Maximum economic payback as function of discount rate.................................... 19

Figure 9. Central air conditioning capital costs and efficiencies available in 2010 .................20

Figure 10. Residential water heater energy use for different scenarios..............................2

Figure 11. North Carolina commercial energy use in Base scenario....................................25

Figure 12. North Carolina commercial energy use in Base scenario....................................26

Figure 13. North Carolina commercial electricity use in Base scenario................................26

Figure 14. Commercial energy prices for the South Atlantic region.....................................28

Figure 15. Commercial energy use for lighting for different scenarios.............................. 31

Figure 16. NEMS Electricity Market Module regions...................................................34

Figure 17. SERC region renewable energy capacity growth in the High Renewable Scenario over

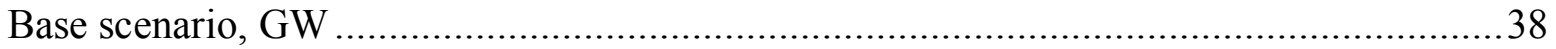





\section{LIST OF TABLES}

Table ES-1. Value of electricity saved in 2020 in Residential and Commercial sectors under different scenarios xii

Table 1. 1999 North Carolina Energy Use by Fuel and Sector in TBtu from SEDS ..................4

Table 2. Ratio of North Carolina energy use to South Atlantic use, \% (EIA 1999a)..................6

Table 3. Energy per person by sector for NC, SA region, and U.S., mmBtu/person/yr ..............6

Table 4. Services and Equipment in the NEMS Residential Sector Demand Module .................9

Table 5. Building types and end-use services in NEMS Commercial Demand Module.............10

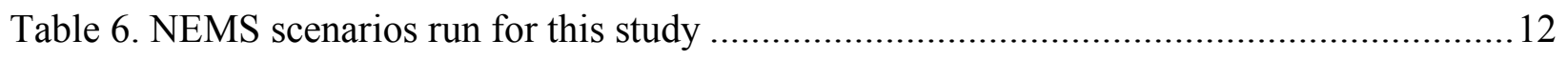

Table 7. North Carolina Base case total residential energy use. .......................................... 16

Table 8. Base case and Lowered Rate case implicit discount rates and equivalent required pay-

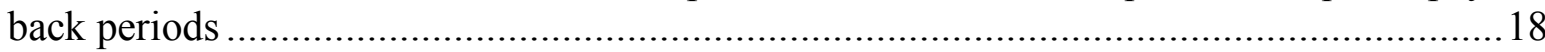

Table 9. Electric water heater costs and efficiencies available in 2010 for Base and High Tech

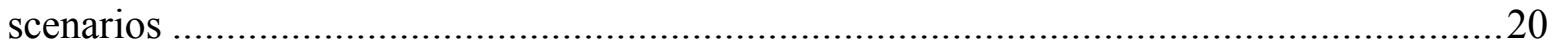

Table 10. North Carolina 2020 residential energy use (Trillion Btu).....................................22

Table 11. Value of electricity saved in 2020 in Residential sector under different scenarios ......23

Table 12. 2000 North Carolina commercial sector energy use. ...........................................27

Table 13. Percentage of commercial customers at each discount rate for each end-use. ............29

Table 14. Commercial equipment efficiency improvements for new equipment with lowered discount rates (Btu out/Btu in) ...........................................................................29

Table 15. North Carolina 2020 commercial energy use from Base, Lowered Discount Rate, High Technology and Best Technology cases (trillion Btu) ............................................ 30

Table 16. Value of electricity saved in 2020 under different scenarios..................................32

Table 17. NC residential renewable energy use (14.1\% of South Atlantic region)....................33

Table 18. NC commercial renewable energy use (19.3\% of South Atlantic region) ..................33

Table 19. SERC region renewable energy capacity in Base scenario, GW ............................35

Table 20. Renewable capital cost and efficiency parameters in Base and High Renewable scenar-

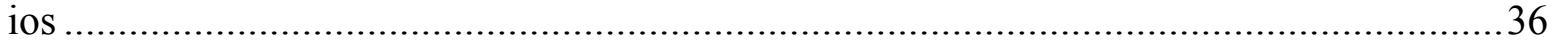

Table 21. Growth in renewable energy use in the High Renewable scenario in the SERC region, GW 37 



\section{ACRONYMS}

$\begin{array}{ll}\text { AEO1999 } & \text { Annual Energy Outlook } 1999 \\ \text { AEO2003 } & \text { Annual Energy Outlook 2003 } \\ \text { CBECS } & \text { Commercial Buildings Energy Consumption Survey } \\ \text { CEF } & \text { Clean Energy Futures study } \\ \text { CHP } & \text { Combined Heat and Power } \\ \text { DOE } & \text { Department of Energy } \\ \text { EIA } & \text { Energy Information Administration } \\ \text { GW } & \text { GigaWatt } \\ \text { GWh } & \text { GigaWatt-hours } \\ \text { kWh } & \text { KiloWatt-hours } \\ \text { mmBtu } & \text { Million British Thermal Units } \\ \text { MW } & \text { MegaWatt } \\ \text { NEMS } & \text { National Energy Modeling System } \\ \text { ORNL } & \text { Oak Ridge National Laboratory } \\ \text { PV } & \text { Photovoltaic } \\ \text { RECS } & \text { Residential Energy Consumption Survey } \\ \text { SEDS } & \text { State Energy Data System } \\ \text { SERC } & \text { Southeastern Electric Reliability Council } \\ \text { TBtu } & \text { Trillion British Thermal Units } \\ \text { TWh } & \text { TeraWatt-hours }\end{array}$





\section{EXECUTIVE SUMMARY}

The purpose of this study was to explore the potential for energy savings and renewable energy in the state of North Carolina. It concentrated on using economic simulation (the National Energy Modeling System or NEMS model) to determine the market potential for energy savings for the residential and commercial sectors and the potential penetration of renewable energy in all sectors.

The NEMS model is used by the Department of Energy's (DOE's) Energy Information Administration (EIA) to calculate twenty-five year projections of energy use for every region of the country. The results of the Annual Energy Outlook 2003 (AEO2003) were used as the Base case. Five alternative scenarios were used to simulate energy savings policies, determine the maximum potential for savings, or identify the renewables most likely to penetrate the North Carolina market. Market-related programs were simulated by lowering the effective discount rates that end-users use when making decisions on equipment purchases. The values to use to represent these programs were based on the Moderate scenario assumptions from the DOE Clean Energy Futures study (IWG 2000). Researchers conducted analyses of a number of residential and commercial programs across the country to determine appropriate values. The scenario assumed increased concern by society on energy efficiency but not to the point of fiscal policies such as taxes or direct subsidies.

Improved end-use equipment was made available under a second scenario to determine the potential for energy savings with equipment improvements. Changes in energy use would indicate that more efficient equipment would be able to penetrate the market, even with consumers deciding on purchases based on their current discount rates. A follow-on scenario combined both the advanced building technologies and lower discount rates to understand how these can work together to increase the amount of savings. Finally, a scenario was run that only allowed customers to purchase the most efficient equipment available. This scenario identifies the maximum amount of energy that foreseeably could be saved by each end-use.

The Residential sector reduced electricity demand by $3.4 \%$ by 2020 through the use of market incentives alone. This represented 2.3 TWh of electricity or $\$ 173$ million in savings in that year alone, at the residential electricity price of $7.6 \phi / \mathrm{kWh}$. The High Technology and High Technology plus Lowered Discount Rates scenarios saved \$271 million and \$463 million annually by 2020, respectively (Table ES-1).

The Commercial sector's market potential for electrical energy savings was calculated to be $6.7 \%$ of its total expected electrical use by 2020 , representing $3.4 \mathrm{TWh}$ of power by 2020 . At the commercial sector price of $6.9 \phi / \mathrm{kWh}$ the savings represent $\$ 237$ million per year and the displacement of a $491 \mathrm{MW}$ power plant. Combining the lowered discount rate with high technology, annual savings reached $\$ 328$ million annually and the equivalent of a $680 \mathrm{MW}$ plant (Table ES-1).

Renewable energy is used both for thermal energy within the residential, commercial, and industrial sectors and for power generation. The NEMS base scenario shows renewable energy continuing to grow within the state and region. Conventional hydro power represents the largest re- 
newable power source, followed by wood and other biomass. The Base scenario shows growth mainly in biomass use in combined heating and power (CHP) applications, at 2.9\% per year. Municipal solid waste (e.g., landfill gas) use also grows by $1.4 \%$ per year. Wind power and photovoltaic show large growth rates for the region, $>20 \%$ per year, but start from a very small base. By 2020 renewable power generation totals $17 \mathrm{GW}$ in the Southeastern Electric Reliability Council (SERC) region. (North Carolina will be $\sim 10 \%$ of that amount.) If advanced renewable technologies are deployed, then another $1.8 \mathrm{GW}$ of renewable power may be built in the region, mainly wood and other biomass using CHP.

Table ES-1. Value of electricity saved in 2020 in Residential and Commercial sectors under different scenarios

\begin{tabular}{|l|cccc|}
\hline & \multicolumn{4}{c}{$\begin{array}{c}\text { High Tech- } \\
\text { nology + } \\
\text { Lowered Dis- }\end{array}$} \\
& $\begin{array}{c}\text { Lowered Dis- } \\
\text { count Rates }\end{array}$ & $\begin{array}{c}\text { High } \\
\text { Technology } \\
\text { count Rates }\end{array}$ & $\begin{array}{c}\text { Best } \\
\text { Technology }\end{array}$ \\
\hline Residential Sector & & & & \\
Energy saved, TBtu & 7.9 & 14.6 & 23.7 & 69.4 \\
Electricity saved, TBtu & 7.8 & 12.2 & 20.8 & 45.5 \\
Value of electricity saved, M\$ & 173 & 271 & 463 & 1013 \\
Displaced capacity ${ }^{\mathrm{a}}, \mathrm{MW}$ & 325 & 508 & 869 & 1902 \\
\hline Commercial Sector & & & & \\
Energy saved, TBtu & 10.9 & 3.9 & 16.5 & 31.6 \\
Electricity saved, TBtu & 11.7 & 3.5 & 16.3 & 28.3 \\
Value of electricity saved, M\$ & 237 & 72 & 328 & 572 \\
Displaced capacity ${ }^{\mathrm{a}}, \mathrm{MW}$ & 491 & 148 & 680 & 1184 \\
\hline
\end{tabular}

${ }^{a}$ Size of a power plant operating at $80 \%$ capacity factor that would generate the amount of electricity saved. Actual capacity could be much higher if electricity savings are from a smaller fraction of the year.

This study only examined some of the potential savings that may be possible. For example, lighting improvements in the residential sector, energy efficiency savings in the industrial sector, and higher efficiency standards were not examined. Programs to encourage the use of renewable energy were not explicitly analyzed beyond technology enhancements to lower costs or improve efficiency. Expansion of studies into these areas may be useful in the future. Also, the growth of miscellaneous other energy uses such as electronics makes these a significant fraction of future demands and may warrant further investigation. Energy savings programs specific to these uses (such as Energy Star) may be helpful in slowing their growth.

Overall, there is a good potential for saving over $6 \%$ of electricity use in North Carolina through a combination of market programs and technology advances, representing over $\$ 400$ million savings per year. Renewable energy growth could be accelerated through technology advancements or incentives to supply several hundred megawatts of additional power as well. With the recent rise in fossil energy costs, state residences and businesses have even greater incentive to save. Active state and utility programs should be able to achieve well over this amount, especially if applied to broader savings measures beyond just those studied here. 


\section{INTRODUCTION}

As many states have restructured their electric power industry, they have established a "systems benefit charge" to help fund those activities that will no longer be funded by utilities in the new structure. Examples include weatherization of low-income housing, efficiency programs, and renewable energy development. Varying amounts have been collected and allocated depending on state needs and abilities. One question that arises is what are the potential results of funding the different types of programs. What is the potential for energy efficiency or for renewable power, and what would be accomplished given the amount of funding that the system benefit charge may provide?

The purpose of this project is to provide an initial estimate of the potential for energy efficiency and renewable energy in North Carolina. This potential could be funded by a public benefits fund resulting from a green power program being considered in the state. It concentrates on electric energy savings and production. Savings in buildings can include improvements to space conditioning as well as improvements to lighting or other appliances. Distributed power potential, through use of combined heat and power and renewables such as photovoltaic, wind, and biomass were examined.

The goal is to provide information to decision makers who are developing a green power program in North Carolina. It will not be a complete and detailed study of all efficiency potentials but is more of a scoping exercise to determine the relative impacts and begin the process for a more definitive study at a later date.

Statewide energy savings potential cannot be directly measured but must be calculated. First, the word "potential" means that the savings have not occurred yet. Second, the savings are often only indirectly measured by estimating what energy use there would have been without the changes in technology or behavior. Calculations through sampling and statistical analysis or by simulation are a necessary part of any mechanism to determine energy savings potential.

There are currently several methods for calculating savings. Extrapolation of savings achieved from specific programs, surveys of existing building stock or energy-using activities, computer calculations of representative building types, and economic simulations all provide insight into the amount of energy that could be saved.

Estimates of potential energy savings available in a given population of facilities generally distinguish between different conceptual approaches (McElhaney and Jallouk 1999). These can be summarized as follows:

- Technical potential denotes energy savings that can be achieved by applying proven energy efficiency technologies to all available opportunities for their use in the population, regardless of the relationship between implementation and cost.

- Economic potential denotes energy savings that can be achieved through a subset of the technically feasible efficiency improvements that meet specified economic criteria. Energy efficiency measures should pass an economic screen (incremental cost versus avoided energy 
and capacity savings) with a "societal test" benefit cost ratio of greater than 1.20 to allow for administrative costs to conduct the program.

- Market potential denotes the energy savings that can be achieved by a subset of economically cost-effective measures that analysts believe the market can deliver during the time horizon of the analysis.

Supply-side constraints on the achievement of economic potential include the lack of awareness of energy efficiency measures and design practices among engineers and conflicting economic incentives for manufacturers or distributors who are principally interested in equipment sales. On the demand side, constraints arise from the competing priorities for capital expenditures and plant maintenance resources.

Differences in the approach used in reporting savings can lead to confusion on the amount of savings actually available. While technical or economic potential savings may be high, the market barriers such as customer inertia, long lives of existing equipment, and limitations in institutional structures will generally greatly lower the amount of savings that will actually occur and slow the penetration of new technologies.

The paper begins with a review of the historical energy use within North Carolina and a comparison to the region and country as a whole (Chapter 2). It then describes the working of the National Energy Modeling System (NEMS) model, which was used for this analysis, and some recent studies that are relevant to this one (Chapter 3). It then provides a detailed analysis of the Residential sector (Chapter 4), the Commercial sector (Chapter 5), and Renewable Energy use (Chapter 6). A summary is then provided in Chapter 7. 


\section{HISTORICAL NC ENERGY USE}

State-specific energy use data is available for each state for the years 1960 through 1999 from the Combined State Energy Data System (SEDS) by the Energy Information Administration (EIA). This data is available from their website and was used in the report State Energy Data Report 1999, Consumption Estimates (EIA 1999a). Projections of future energy use are also available from various studies that have been done by EIA, most notably the Annual Energy Outlook 2003 (EIA 2003a) (AEO2003) that was used as the basis for much of this study.

\subsection{ENERGY USE BY SECTOR}

North Carolina energy use can be broken down by source of power and by sector. In Figure 1 the historical amounts of energy by end-use sector are shown. Table 1 and Figure 2 show the 1999 energy use by source for the various end-use sectors. Electricity use in the end-use sectors does not include the losses associated with the electricity production. Rather, the final column shows the primary energy use in the Electricity sector. Its total matches the sum of the electricity enduse from the other sectors and the losses associated with making electricity.

Figure 1. Primary energy use within North Carolina, 1960-1999 from SEDS

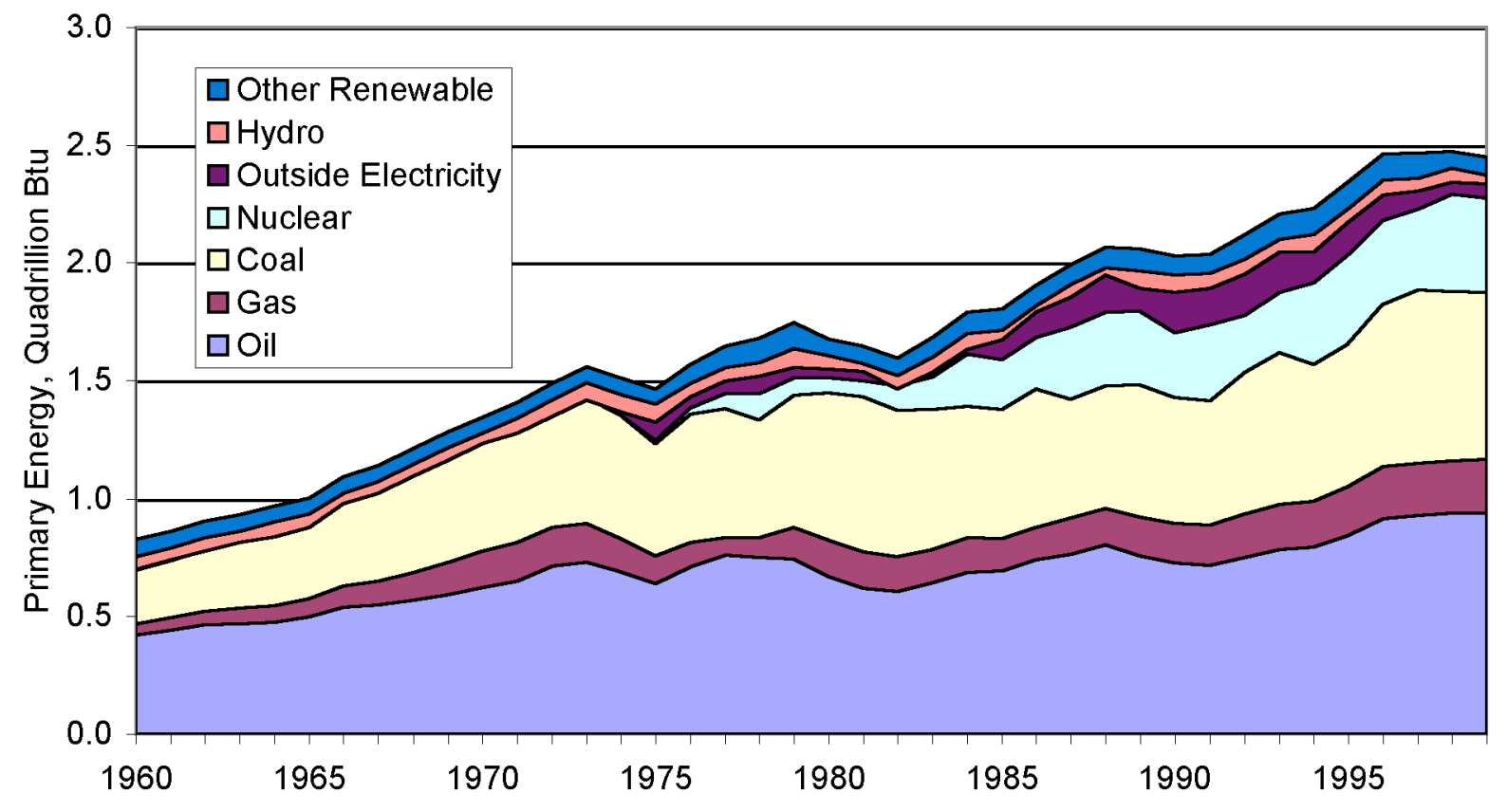

Source: EIA 1999a 
Table 1. 1999 North Carolina Energy Use by Fuel and Sector in TBtu from SEDS

\begin{tabular}{|l|rrrrrr|}
\hline \multicolumn{1}{|c|}{ FuellSector } & Residential & Commercial & Industrial & Transport & Electrical & Total \\
\hline Petroleum & 52 & 20 & 181 & 680 & 4 & 937 \\
Gas & 55 & 39 & 113 & 11 & 11 & 229 \\
Coal & 1 & 2 & 44 & 0.0 & 660 & 708 \\
Nuclear & & & & & 399 & 399 \\
Electricity & 149 & 127 & 117 & 0.0 & & 392 \\
Hydro & & & 12 & & 28 & 40 \\
Other Renewable & 14 & 2 & 58 & 0.0 & 0.0 & 74 \\
\cline { 2 - 7 } Total End-Use & 271 & 191 & 525 & 691 & 1101 & $1678^{\mathrm{c}}$ \\
\% of State Total & $16 \%$ & $11 \%$ & $31 \%$ & $41 \%$ & & \\
Electric losses & $292^{\mathrm{a}}$ & $249^{\mathrm{a}}$ & $228^{\mathrm{a}}$ & 0.0 & $61^{\mathrm{b}}$ & $769^{\mathrm{c}}$ \\
\cline { 2 - 7 } Total w/ losses & 563 & 440 & 754 & 691 & 1161 & $2447^{\mathrm{c}}$ \\
\% of Total w/ losses & $23 \%$ & $18 \%$ & $31 \%$ & $28 \%$ & & \\
\hline
\end{tabular}

${ }^{a}$ Energy lost when converting primary energy (coal, gas, etc.) to electricity at electric power plants and T\&D losses

${ }^{\mathrm{b}}$ Represents electricity imports that make up difference between electricity generation (1101 TBtu) and total enduse plus losses (1161 TBtu).

${ }^{\mathrm{c}}$ Does not include electrical industry amounts since these are included in end-use sectors.

Source: EIA 1999a

Figure 2. 1999 energy use in North Carolina

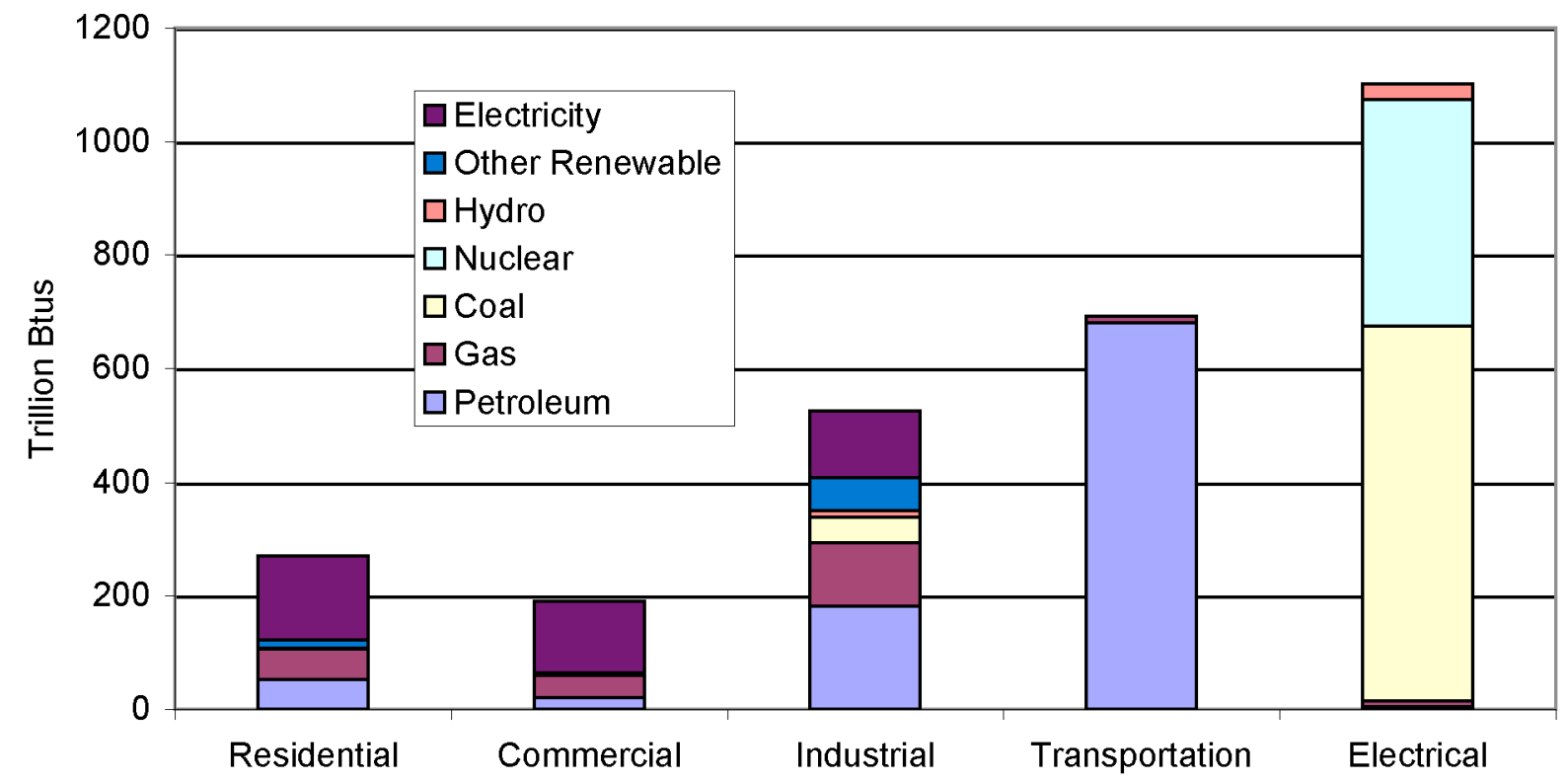

Source: EIA 1999a

Residential energy use is dominated by electricity purchases. Over 55\% of the 271 TBtu used in the sector was from electricity, not including the additional primary energy loss in the generation, transmission, and distribution of the electricity. Over $97 \%$ of the $14.1 \mathrm{TBtu}$ of renewable energy use is from wood used in heating, with the rest either solar thermal or geothermal energy. 
Petroleum use includes liquid petroleum gas (LPG) at 23.3 TBtu, distillate fuel at 17.4 TBtu, and others such as kerosene at 11.3 TBtu.

Commercial use was even more dominated by electricity than the residential sector, providing over $66 \%$ of all end-use energy. Natural gas provided roughly the same fraction of energy as in the residential sector, $\sim 20 \%$, but petroleum products played a much smaller role.

Industrial energy use was widely distributed between sources, with petroleum being the largest contributor at $34 \%$. Natural gas and electricity each provided around $22 \%$ of the energy needs for the sector. Hydro power contributed some energy to the industrial sector in North Carolina, and other renewables contributed a relatively significant proportion (11\%). This amount comes from the use of wood and waste products.

\subsection{COMPARISON TO REGION AND COUNTRY}

Surveys of different end-use sectors can provide information on the energy-saving potential within their activities. The EIA periodically conducts national surveys of the residential and commercial building energy use. The most recent residential survey is A Look at Residential Energy Consumption in 1997 (EIA 1999b) (commonly called RECS) and the most recent commercial survey, A Look at Commercial Buildings in 1999: Characteristics, Energy Consumption, and Energy Expenditures (EIA 2002b), is often called CBECS. These surveys provide details on the type of equipment used, age, building characteristics, occupants, energy use, and other information to provide a portrait of building stock across the US.

Figure 3. South Atlantic region

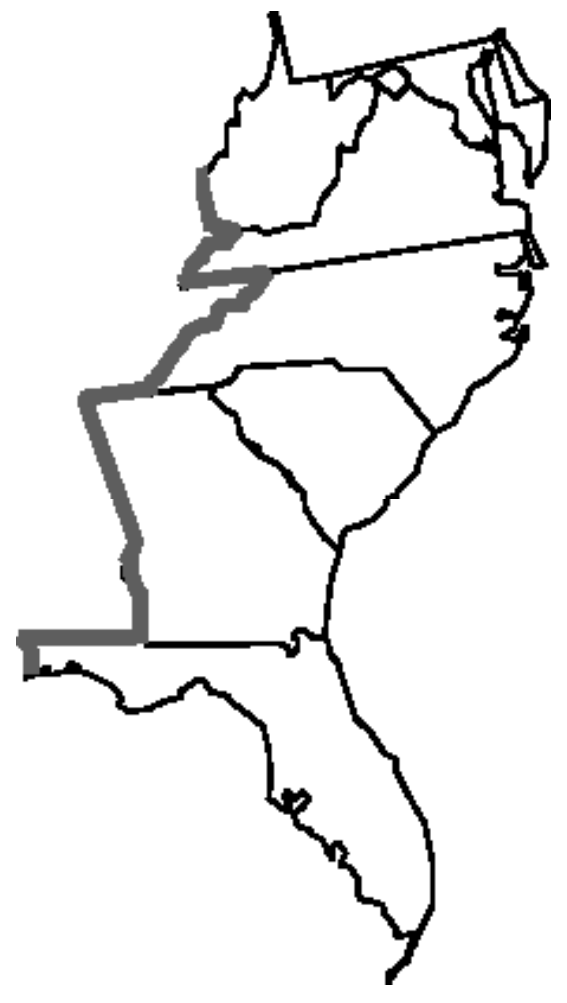

The data from the two surveys is used in the forecasting model used for this study, NEMS. (See Section 3 for a more detailed description of the model.) The key difficulty is that the data provided by the survey and in the model are only at the regional, rather than state level, making results difficult to apply to North Carolina alone. The survey separates the nation into nine geographical regions. North Carolina is part of the South Atlantic region, which includes Delaware, Maryland, the District of Columbia, Virginia, West Virginia, South Carolina, Georgia, and Florida as well (Figure $3)$.

To approximate the values for North Carolina, we combined the values for all nine states (including DC) from the Combined State Energy Data System used above. We then found the ratio of energy use by fuel and sector for North Carolina as compared to the total for all nine states (Table 2). To avoid anomalies from single year values, we combined the data for 1997-1999. Most percentages changed little between years. Applying the resulting percentages to regional energy use from NEMS gives an approximate amount for 
North Carolina.

Table 2. Ratio of North Carolina energy use to South Atlantic use, \% (EIA 1999a)

\begin{tabular}{|lccc|}
\hline \multicolumn{1}{c}{ FuellSector } & Residential & Commercial & Industrial \\
Distillate & 21 & 20 & 15 \\
LPG & 28 & 28 & 40 \\
Other Pet & 39 & 21 & 22 \\
Gas & 13 & 12 & 15 \\
Coal & 27 & 27 & 13 \\
Electricity & 16 & 15 & 21 \\
Hydro & - & - & 33 \\
Other Renewable & 14 & 19 & 11 \\
Net Total & 16 & 15 & 17 \\
\hline
\end{tabular}

Source: EIA 1999a

Energy use per capita for North Carolina can be compared to the South Atlantic (SA) region and to the U.S. as a whole (Table 3). It shows that North Carolinians use relatively small amounts of natural gas compared to the country as a whole, in all of the end-use sectors. In the Residential and Commercial sectors, North Carolinians used somewhat similar total amounts as the region and country as a whole $( \pm 10 \%)$, while their industrial use was significantly less than the U.S. as a whole. Electrical use, and coal and nuclear as components of that generation, was higher in North Carolina.

Table 3. Energy per person by sector for NC, SA region, and U.S., mmBtu/person/yr

\begin{tabular}{|c|c|c|c|c|c|c|c|c|c|c|c|c|c|c|c|c|c|c|}
\hline \multirow[t]{2}{*}{$\begin{array}{l}\text { Fuel/ } \\
\text { Sector }\end{array}$} & \multicolumn{3}{|c|}{ Residential } & \multicolumn{3}{|c|}{ Commercial } & \multicolumn{3}{|c|}{ Industrial } & \multicolumn{3}{|c|}{ Transportation } & \multicolumn{3}{|c|}{ Electrical } & \multicolumn{3}{|c|}{ Total } \\
\hline & $\mathrm{NC}$ & SA & US & $\mathrm{NC}$ & SA & US & $\mathrm{NC}$ & SA & US & $\mathrm{NC}$ & SA & US & $\mathrm{NC}$ & SA & US & $\mathrm{NC}$ & SA & US \\
\hline Petroleum & 7 & 4 & 5 & 3 & 2 & 2 & 24 & 17 & 34 & 89 & 92 & 94 & 0 & 10 & 3 & 122 & 125 & 139 \\
\hline Gas & 7 & 8 & 18 & 5 & 6 & 11 & 15 & 15 & 38 & 1 & 2 & 3 & 1 & 9 & 12 & 30 & 40 & 82 \\
\hline Coal & 0 & 0 & 0 & 0 & 0 & 0 & 6 & 7 & 8 & 0 & 0 & 0 & 86 & 79 & 67 & 92 & 87 & 75 \\
\hline Nuclear & 0 & 0 & 0 & 0 & 0 & 0 & 0 & 0 & 0 & 0 & 0 & 0 & 52 & 41 & 28 & 52 & 41 & 28 \\
\hline Electricity & 19 & 19 & 14 & 17 & 17 & 14 & 15 & 11 & 13 & 0 & 0 & 0 & 0 & 0 & 0 & 51 & 47 & 41 \\
\hline Hydro & 0 & 0 & 0 & 0 & 0 & 0 & 2 & 0 & 1 & 0 & 0 & 0 & 4 & 2 & 11 & 5 & 2 & 13 \\
\hline Renewable & 2 & 2 & 2 & 0 & 0 & 0 & 8 & 13 & 11 & 0 & 0 & 0 & 0 & 0 & 0 & 10 & 15 & 13 \\
\hline Net Total & 35 & 33 & 39 & 25 & 26 & 28 & 69 & 65 & 106 & 90 & 93 & 96 & 144 & 140 & 123 & 219 & 217 & 270 \\
\hline E losses & 38 & 37 & 28 & 33 & 33 & 27 & 30 & 22 & 26 & 0 & 0 & 0 & 8 & 0 & 0 & 100 & 93 & 81 \\
\hline Total & 74 & 71 & 67 & 57 & 59 & 55 & 99 & 87 & 132 & 90 & 93 & 97 & 152 & 140 & 123 & 320 & 310 & 351 \\
\hline
\end{tabular}

Source: EIA 1999a 


\section{ECONOMIC MODELING WITH NEMS}

Economic simulation involves modeling the economic decision-making of an energy-using sector or entire region. The stock of existing buildings and equipment, data on options available, decision procedures, energy prices, etc. need to be available for the model to attempt to realistically simulate the purchase behavior of people. Even with adequate data, there will always be disagreements on some of the more subjective criteria, such as importance of energy efficiency versus other product characteristics, or market inertia of consumers towards changing consumer preferences. Nevertheless, this method of calculation is necessary to determine the market potential of energy savings equipment and technologies.

\subsection{NEMS MODEL}

The most widely recognized economic simulation model is the National Energy Modeling System (NEMS). The EIA developed this model to forecast national and regional energy supply and demand through 2025 . The model is continuously being modified for various studies by EIA; the version used for this study is the one used for the recent Annual Energy Outlook 2003 (EIA 2003a).The model allows a wide variety of parameters to be altered to determine their impact on overall fuel use. Examples include changes in equipment efficiencies, costs, fuel supplies, economic growth, and consumer preferences. Detailed information on the model can be found on their website at http://www.eia.doe.gov/bookshelf/docs.html.

NEMS models the major end-use sectors of the economy: residential, commercial, industrial, and transportation. Within the energy sector it models the electricity sector, oil, gas, and coal production, and renewable energy. It separates the nation into nine geographical regions. North Carolina is part of the South Atlantic region, which includes Delaware, Maryland, the District of Columbia, Virginia, West Virginia, South Carolina, Georgia, and Florida as well.

Figure 4 from the NEMS Overview shows the overall flow of the NEMS model between the various sectors. Each module uses inputs from data sets provided by the user along with calculated values from the other modules in order to calculate its results. Because of the feedback between supply and demand, some iteration is required. Key results can be stored from runs to allow for repetition of cases without having to run the full model. Only the residential and commercial demand modules were modified and rerun, thereby saving recalculation time. Energy prices are consequently kept constant between all scenarios. 
Figure 4. National Energy Modeling System Integration

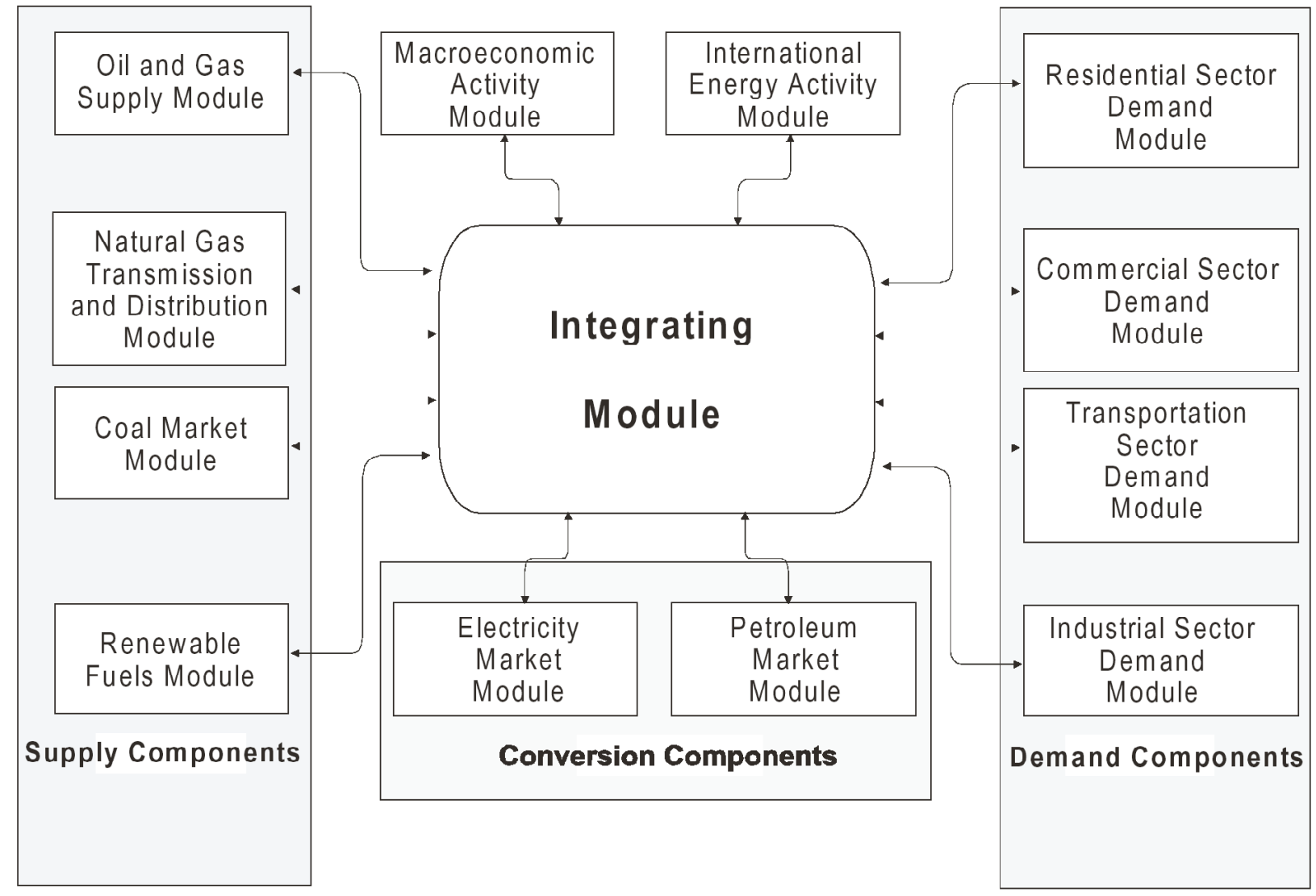

Source EIA 2001

\subsubsection{Residential Analysis in NEMS}

The residential module controls the calculations involving energy use within the residential sector, including single-family dwellings, multi-family dwellings, and mobile homes. Base year housing data, appliance types and efficiencies, and other data are provided by inputs from the user. Other NEMS modules provide information such as energy prices and economic growth. The module calculates housing stock, appliance needs, and distributed energy use to determine energy demands. These are then fed back to the other modules if they are to be called upon for recalculation, and to the output reports.

Residential and commercial sectors have a number of end-uses modeled (Table 4 and Table 5). Each major end-use has a number of different technologies available. Within each technology (e.g., natural gas furnace) there may be many different types of equipment available at a variety of costs and efficiencies.

Besides the major end-uses modeled within NEMS, a "Miscellaneous Other" category is included. The Other category in the residential sector includes a variety of smaller end-uses, including, personal computers, color televisions, furnace fans, small kitchen appliances, other home electronics, and all of the other unidentified energy end-uses. It also includes adjustments 
to ensure that each region and sector's energy-use matches the totals as reported in EIA's State Energy Data Report (EIA 1999a).

\section{Table 4. Services and Equipment in the NEMS Residential Sector Demand Module}

\begin{tabular}{|ll|}
\hline Space Heating Equipment & Cookstoves \\
Electric Furnace & Natural Gas \\
Electric Air-Source Heat Pump & LPG \\
Natural Gas Furnace & Electric \\
Natural Gas Other (Hydronic) & \\
Kerosene Furnace & Clothes Dryers \\
LPG Furnace & Natural Gas \\
Distillate Furnace & Electric \\
Distillate Other (Hydronic) & \\
Wood Stove & Refrigerators \\
Electric Ground-Source Heat Pump & 18 cubic-foot Top Mounted Freezer \\
Natural Gas Heat Pump & 24 cubic-foot Side-by-Side with \\
& Through-the-Door Features \\
Space Cooling Equipment & Water Heaters \\
Electric Room Air Conditioner & Natural Gas \\
Central Air Conditioner & Electric Resistance / Heat Pump \\
Electric Air-Source Heat Pump & Distillate \\
Electric Ground-Source Heat Pump & LPG \\
Natural Gas Heat Pump & Solar Thermal \\
& \\
Freezers & Lighting \\
Chest Manual Defrost & Incandescent \\
Upright Manual Defrost & Compact Fluorescent \\
Clothes Washers & Halogen Torchiere \\
Vertical Axis & \\
Horizontal Axis & Dishwasher \\
\hline
\end{tabular}

\subsubsection{Commercial Analysis in NEMS}

The residential and commercial sectors are largely defined by the types of buildings used. The residential sector is split between single-family dwellings, multi-family dwellings, and mobile homes. The commercial sector is separated by the type of activities. NEMS models eleven different businesses: assembly, education, food sales, food service, health care, lodging, large office, small office, mercantile \& service, warehouse, and other. For each type of building NEMS maintains information on end-use service, fuel, equipment used, energy prices, customer purchasing preferences, age distribution of buildings, etc.

As with the residential module, exogenous data is provided by the user and calculated values from the other modules. Floorspace and consequent end-services calculations are made. Technology choices are determined, resulting in the energy use for each region and commercial building type. 
For each type of end-use service (heating, cooling, water heating, etc.) different technologies are available. The model maintains data on capital cost, efficiency, type of fuel used, purchase preference criteria, and dates of availability for each type of equipment. This allows the model to bring on new equipment and retire older equipment throughout the study period. To bring on new equipment it calculates the life cycle cost of each technology, and selects a mixture based on the relative cost of each. The life cycle cost includes the capital (or replacement) cost plus future costs of the energy needed discounted using an input discount rate. The discount rates are higher than just the cost of money to reflect customer resistance or insensitivity to ongoing costs versus initial cost. In addition, the model places limits on the amount of technology or fuel switching for various types of customers, based on historical survey data from RECS and CBECS.

The commercial sector has a number of end-uses modeled (Table 5). Each major end-use has a number of different technologies available. Within each technology (e.g., natural gas furnace) there may be many different types of equipment available at a variety of costs and efficiencies. Values for these equipment types are listed in Section 4.1.

Besides the major end-uses modeled within NEMS, a "Miscellaneous Other" category is included. The Other category contains transformers, traffic lights, exit signs, district services, automated teller machines, telecommunications equipment, medical equipment, and other unidentified end-uses. It also includes an adjustment term to ensure that the total commercial sector energy use adds up to the totals reported in EIA's SEDS (EIA 1999a).

Table 5. Building types and end-use services in NEMS Commercial Demand Module

\begin{tabular}{|l|l|}
\hline Building Types & End-Use Services \\
\hline Assembly & Space Heating \\
Education & Space Cooling \\
Food Sales & Water Heating \\
Food Service & Ventilation \\
Health Care & Cooking \\
Lodging & Lighting \\
Office - Large & Refrigeration \\
Office - Small & Office Equipment - PCs \\
Mercantile \& Service & Office Equipment - Other \\
Warehouse & Other \\
\hline
\end{tabular}

\subsubsection{Renewables modeling in NEMS}

Renewable energy is modeled in two main ways in NEMS. End-use specific forms of renewable energy are modeled within the end-use sectors, (e.g., biomass in the industrial sector, ethanol in the Petroleum Market Module (PMM), wood in the residential sector, geothermal heat pumps and distributed (grid-connected) solar photovoltaics in the residential and commercial sectors, and solar hot water heating in the residential sector)(EIA 2002a). Most renewable energy, however, is modeled within the electricity sector. The Electricity Market Module (EMM) combines information from multiple supply and demand modules to determine the make-up of the electricity market over the study period. 
Conventional hydro power is modeled directly in the EMM but other renewable sources are modeled in the Renewable Fuels Module (RFM). The RFM calculates the cost, performance, and resource size characteristics for the various renewable technologies: landfill gas (municipal solid waste), wind, solar (central station thermal or photovoltaic (PV)), biomass, and geothermal.

Detailed regional parameters are used to convert the characteristics of the technology to values for use in the EMM. For example, wind energy potential is represented by the amount of land area at different classes of wind for each census region. Costs are added to the capital costs in various regions based on the distance from transmission lines and rate of expansion in the region. These are converted into the form of energy supply curves. The supply curves provide the maximum amount of turbine generating capacity that could be installed, given the available land area, average wind speed, and capacity factor. These variables are passed to EMM in the form of nine time segments (derived from three 8-hour segments of the day for three seasons: winter, summer and spring/fall) that are matched to electricity load curves within EMM. (EIA 2002a)

\subsection{ANNUAL ENERGY OUTLOOK 2003}

The AEO2003 was published in December 2002 and provides a reference projection of energy supply and demand through 2025 for each region of the country. The analysis was conducted by the Energy Information Administration. They state in the preface to the report:

The projections in AEO2003 are not statements of what will happen but of what might happen, given the assumptions and methodologies used. The projections are business-asusual trend forecasts, given known technology, technological and demographic trends, and current laws and regulations. Thus, they provide a policy-neutral reference case that can be used to analyze policy initiatives. (EIA 2003a)

\subsubsection{Regional analysis}

Most of the reports from the AEO2003 show the results for the country as a whole. However, some reports are available for the different regions of the country. In addition, the NEMS model produces more detailed data in intermediate reports or has them available within the model. These detailed reports and data output from the model were used to determine the energy outlook for the South Atlantic region. The values for the energy use for each source and end-use sector were multiplied by the percentages in Table 2 to approximate the values for North Carolina.

\subsubsection{Alternate scenarios}

In addition to the Base scenario, the EIA analyzed a number of sensitivities. For this study we selected three of their alternate scenarios plus conducted two of our own (Table 6). We chose to consider the high building, best building, and high renewable scenarios from EIA. We then ran one scenario in which we lowered the discount rates for residential and commercial customers based on the discount rate values from the Clean Energy Futures study (IWG 2000). This is similar to the Iowa study (Hadley 2001), but showed less impact because EIA had already incorporated some of the lower discount rates into their reference scenario. Each scenario has modifications to the capabilities of the considered technologies, and/or modifications to the way the 
model selects between technologies. Advanced technologies may be made available sooner, with better efficiencies, lower costs, or greater acceptance from consumers. As a final scenario, we combined the high building technologies and the lowered discount rates to see the consolidated impact of both improvements in technology and better customer acceptance.

Table 6. NEMS scenarios run for this study

\begin{tabular}{|ll|}
\hline Scenario name & Description \\
\hline Base & Reference case \\
Building Best & Buildings-best available technology \\
Building High Tech & Buildings-advanced technology \\
High Renewables & high renewable penetration \\
Lower Discount Rates & Reduce residential and commercial discount rates based \\
& on Clean Energy Futures and lowa studies \\
Building High Tech + Lower Dis- & Advanced technology for buildings and reduced discount \\
count Rates & rates based on CEF and lowa studies \\
\hline
\end{tabular}

\subsubsection{Clean Energy Futures}

During 1999 and 2000 a major study was commissioned by the DOE on the effects of possible policies to reduce energy use or emissions. The resulting report, Scenarios for a Clean Energy Future (also known as the CEF study) (Interlaboratory Working Group 2000) used a modified version of the NEMS model to integrate the analysis of policy impacts on the various sectors of the economy. Three main scenarios were developed: a Business as Usual scenario that was similar to the Annual Energy Outlook 1999 (AEO1999) but with minor changes due to improved data; a Moderate scenario with policies that did not involve major cost burdens on the economy; and an Advanced scenario that included more far-reaching policies such as a carbon cap and trade system. The study concentrated on national results rather than regional impacts. Consequently, little data is available on the impact of these policies on North Carolina or the South Atlantic region.

National energy savings from the policies within the CEF study are shown in Figure 5. Moderate scenario savings are around $8 \%$ of the Business-As-Usual energy use by 2020 . The additional policies of the Advanced scenario save even more, to where total energy use actually declines. However, this study of North Carolina only considered a subset of the Moderate scenario policies; consequently, overall savings were less. We analyzed voluntary programs that lowered discount rates and improved technologies in the residential and commercial sectors, but we did not analyze the industrial or transportation sectors, and the electricity sector analysis only included modifications to renewable energy sources based on recent EIA estimates. 
Figure 5. Clean Energy Futures Study national savings amounts

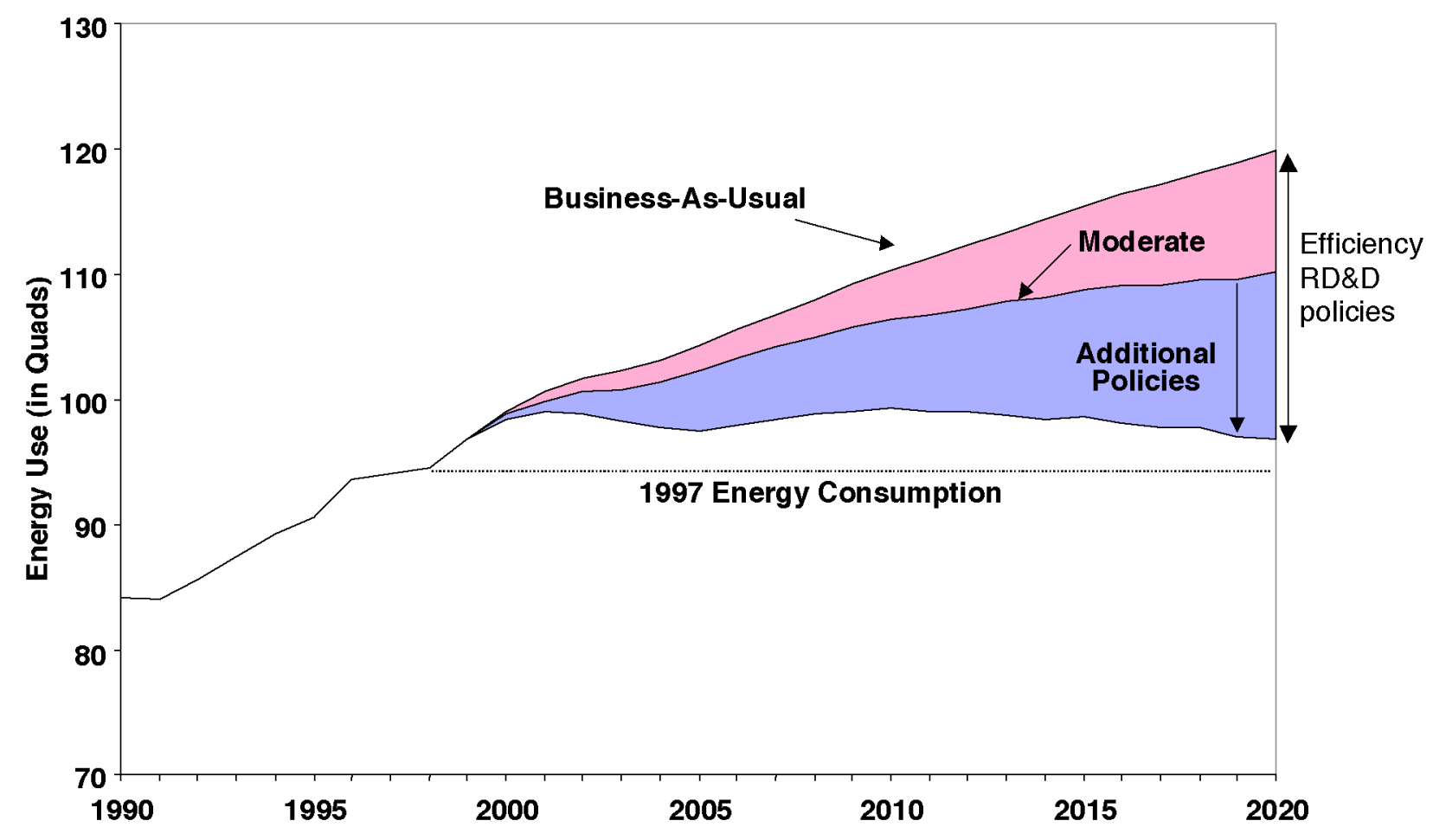




\section{RESIDENTIAL ENERGY ANALYSIS}

The NEMS reference scenario from the AEO2003 provides information on energy use in the residential sector from 1998 to 2025, but we will be examining the results for between 2000 and 2020. The reference data in 2000 closely matches the data in Table 1, although some differences arise because of the year difference (Table 1 is for 1999) and limitations in the model.

\subsection{REFERENCE ENERGY USE}

In 1999, the residential end-use sector represented just $16 \%$ of total end-use consumption (Table 1). While the most readily visible energy-using sector, it is not the largest. Space heating makes up the bulk of energy use in the sector, with water heating being the next largest (Table 7). These services are largely performed by natural gas, with some energy provided by electricity, distillate, LPG, coal, kerosene, and wood.

As shown in Figure 6, the major end uses for electricity currently are lighting, space cooling, space heating, and water heating. The "other" category in Table 7 is separated into three categories within NEMS and in Figure 6: electric motors, heating elements, and other electronic appliances such as computer peripherals, stereos, VCR's, and DVD players. These "plug loads" are expected to see significant growth over time, especially electronics, becoming among the largest end-uses for electricity in the home.

Figure 6. North Carolina residential electrical end-use in Base scenario

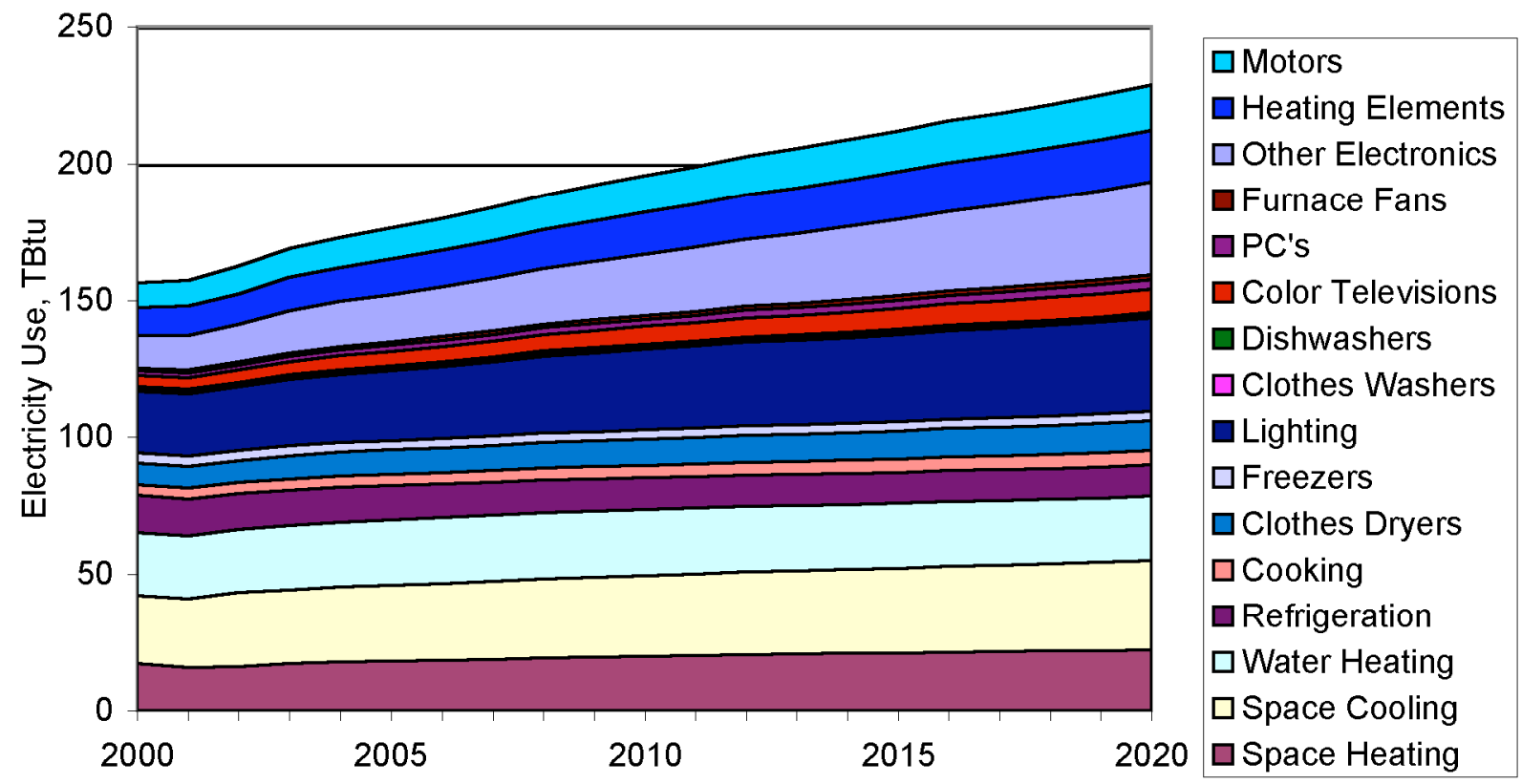


Table 7. North Carolina Base case total residential energy use. Green rows show totals for each major end-use; indented rows below each shaded row show the break-down by fuel.

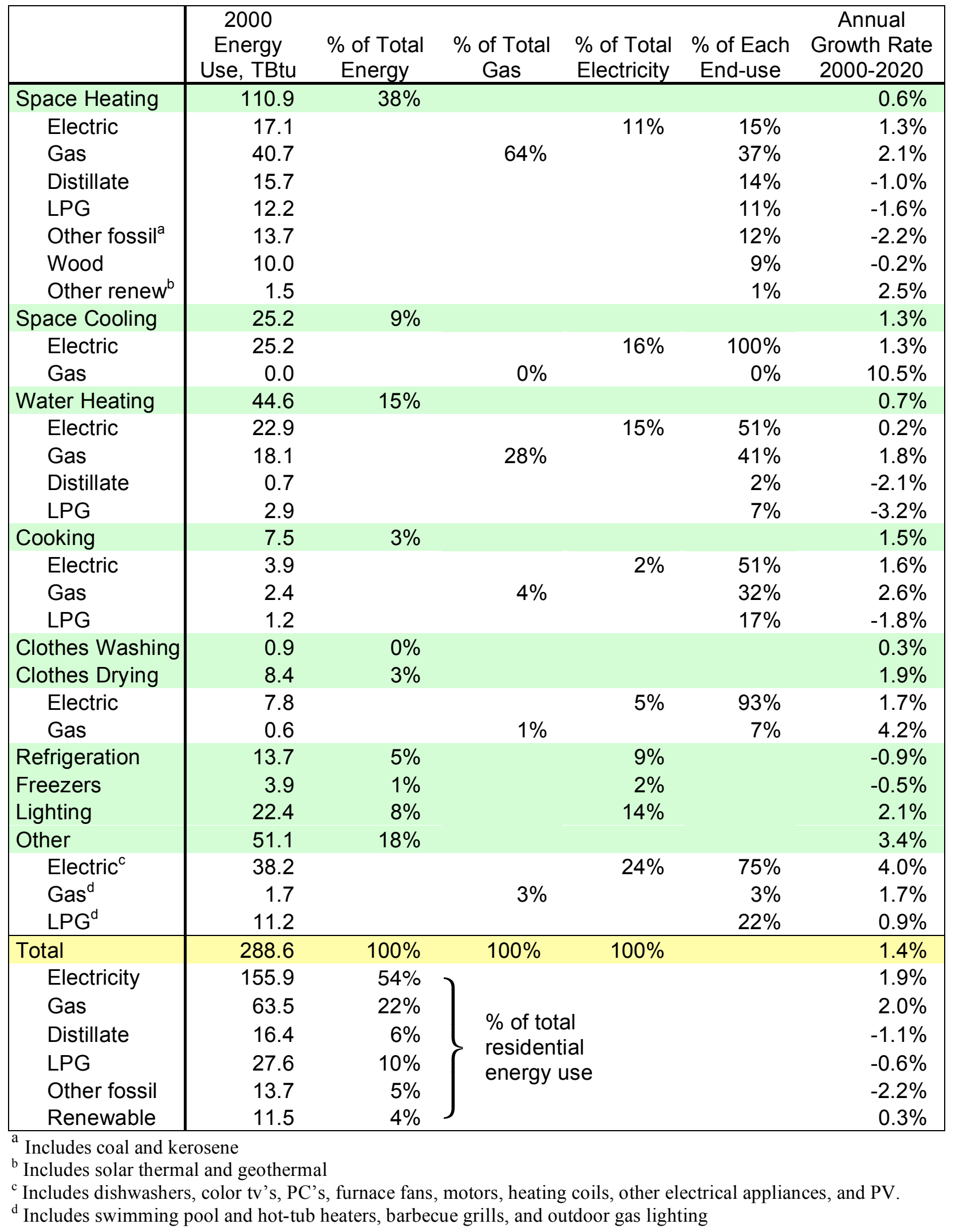


Projected residential energy prices in $\$ / \mathrm{mmBtu}$ for the region are shown in Figure 7 . An electricity price of $\$ 22 / \mathrm{mmBtu}$ translates into $7.5 \phi / \mathrm{kWh}$. The natural gas prices are roughly $12 \%$ above the national average and the LPG price are about $20 \%$ higher; electricity prices are about $2 \%$ lower. Gas and LPG prices are likely higher than the national average because of distance from natural gas reserves and refineries that produce LPG. Whether this applies to just the region as a whole or to North Carolina as well is unknown.

\section{Figure 7. Residential energy prices for the South Atlantic region}

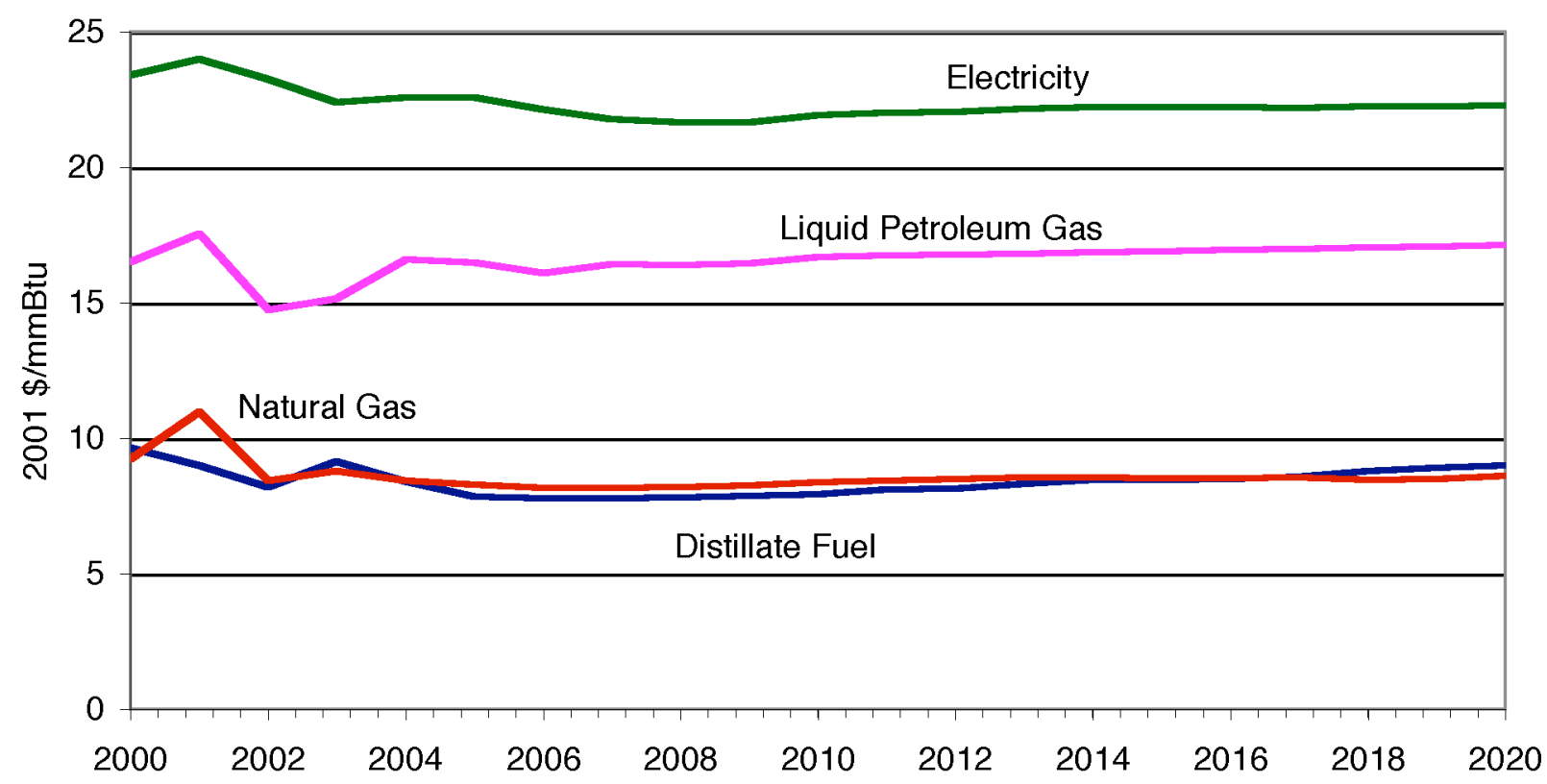

\subsection{IMPROVEMENTS}

Four scenarios were run with impacts on the residential sector. Two scenarios with improvements to technologies, one with lowered discount rates, and one with both improvements to technologies and lowered discount rates.

The discount rate scenarios reduced the hurdle rate the customers use when evaluating the nearterm and long-term costs of technology choices. For the CEF study, several methods were used to model policy changes to improve efficiency. Outside calculations were done to estimate the impact of various energy saving programs (e.g., Energy Star appliances and homes, Rebuild America) on energy use. The results from field studies and simulations were used to project savings on a broader scale if the programs were more fully implemented. As one method to model the different energy policies, various parameters within the inputs or programming for the CEFNEMS model were changed to replicate the results of these outside calculations. (The CEF study used a modified version of the NEMS program as used in the AEO1999. Consequently, it was named CEF-NEMS to avoid confusion.) 
Many energy efficient technologies are cost-effective on a life cycle basis despite their higher initial cost. The lower operating costs due to higher efficiencies offset the higher initial cost. Market barriers, lack of knowledge about future costs, customer emphasis on lowest initial cost or non-cost factors lead to lack of acceptance of these cost-effective options. NEMS models this resistance by using a high discount rate (as a weighted bias between capital and discounted operating costs) and thereby making future costs less important in the decision process. The model uses a log-linear function that incorporates other factors in the decision process such as consumer preference parameters, besides just capital cost and energy savings. Table 8 shows the discount rates in the Base and Lowered Rate cases for key technologies.

Table 8. Base case and Lowered Rate case implicit discount rates and equivalent required payback periods

\begin{tabular}{|l|cc|cc|c|}
\hline \multirow{2}{*}{ Technology } & \multicolumn{2}{|c|}{ Base Case } & \multicolumn{2}{c|}{ Lowered Rates } & \\
\cline { 2 - 5 } & $\begin{array}{c}\text { Discount } \\
\text { Rates }\end{array}$ & $\begin{array}{c}\text { Required } \\
\text { Payback } \\
\text { (years) }\end{array}$ & $\begin{array}{c}\text { Discount } \\
\text { Rates }\end{array}$ & $\begin{array}{c}\text { Required } \\
\text { Payback } \\
\text { (years) }\end{array}$ & Period \\
\hline Electric water heater & $83 \%$ & 0.8 & $20 \%$ & 3.5 & $2004-2025$ \\
Solar water heater & $83 \%$ & 0.8 & $20 \%$ & 3.5 & $2004-2025$ \\
Gas water heater & $47 \%$ & 1.5 & $15 \%$ & 4.6 & $2004-2025$ \\
LPG water heater & $47 \%$ & 1.5 & $15 \%$ & 4.6 & $2004-2025$ \\
Distillate water heater & $150 \%$ & 0.5 & $15 \%$ & 4.6 & $2004-2025$ \\
Room air conditioners & $142 \%$ & 0.5 & $15 \%$ & 4.6 & $2004-2025$ \\
Central air conditioners & $25 \%$ & 2.8 & $15 \%$ & 4.6 & $2004-2025$ \\
Clothes washers & $391 \%$ & 0.2 & $15 \%$ & 4.6 & $2004-2025$ \\
Electric clothes dryers & $90 \%$ & 0.8 & $15 \%$ & 4.6 & $2004-2025$ \\
Gas dryers & $47 \%$ & 1.5 & $15 \%$ & 4.6 & $2004-2025$ \\
Refrigerators & $19 \%$ & 3.6 & $15 \%$ & 4.6 & $2004-2025$ \\
Freezers & $37 \%$ & 1.9 & $15 \%$ & 4.6 & $2004-2025$ \\
\hline
\end{tabular}

Another way to view customer economic preferences is through the number of years for energy cost savings to "pay back" the initial investment. A discount rate can be converted into the payback years by:

Payback $=\ln (2) /$ discount rate $=0.693 /$ discount rate

This formula is the basis for calculating the time it takes to double an investment depending on the interest rate: divide 70 by the interest rate in percent. A $14 \%$ interest rate would double in five years, or consumers using a 14\% discount rate would require a maximum payback of five years for the project to be economic. If the payback took longer then the consumer would consider it uneconomic. This relationship is shown in Figure 8. High discount rates imply that customers would require operational savings to pay for the extra up-front cost in less than two years. Table 8 shows in how few years the savings must pay back the extra cost of a more efficient appliance before customers would consider the savings worthwhile. (Because NEMS uses a logit function in allocating purchase decisions between technologies, a proportion of sales will occur even when savings do not meet the payback period.) 
This analysis used the discount rate changes from the Moderate scenario of the CEF study. It did not include changes to the costs of technologies or internal coding changes that modified technologies such as lighting or others. Alternatively, lowered costs can imply a subsidy from the state on the capital cost of the equipment, but then it requires outside calculations using the projected energy prices to determine whether the subsidies are worthwhile from a societal perspective. Lowering the discount rate, but still keeping it at or above the cost of capital, represents a lowering of the risks, real or perceived, and transaction costs to consumers. Any purchase decisions are still cost-effective if barriers or information gaps are reduced. A $15 \%$ rate, while lower than some credit card rates for consumer purchases, is still higher than typical mortgages or home improvement loans.

\section{Figure 8. Maximum economic payback as function of discount rate}

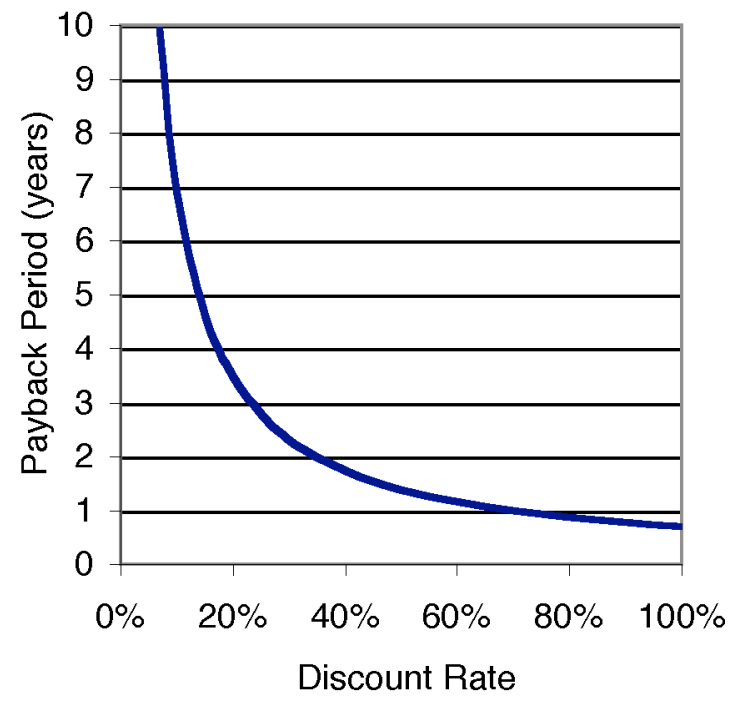

State policies may not have much effect on advances in technology cost and efficiency. However, scenarios using changes in technology provide information on the amount of energy savings potentially available for that end-use. The Assumptions to the Annual Energy Outlook 2003(EIA 2003b) describes these two cases as follows:

The high technology case assumes earlier availability, lower costs, and/or higher efficiencies for more advanced equipment than the reference case. Equipment assumptions were developed by engineering technology experts, considering the potential impact on technology given increased research and development into more advanced technologies.10 In the high technology case, heating shell ${ }^{1}$ efficiency increases by 12 percent and cooling shell efficiency by 5 percent, relative to 1997 .

The best available technology case assumes that all equipment purchases from 2003 forward are based on the highest available efficiency in the high technology case in a particular simulation year, disregarding the economic costs of such a case. It is merely designed to show how much the choice of the highest-efficiency equipment could affect energy consumption. In this case, heating shell efficiency increases by 16 percent and cooling shell efficiency by 6 percent, relative to 1997 .

Technology improvements were made available in each of the categories. However, this does not necessarily mean that overall usage will improve significantly. NEMS operates by having multiple types of each technology available at different efficiencies and capital costs. NEMS models consumer decision-making by examining the near-term and long-term costs of each technology. In addition, limits are placed in the model on what fraction of consumers will consider switching to new fuel types or technologies. There are often barriers to consumers switching from electricity to natural gas or room air conditioners to central air.

${ }^{1}$ Heating and cooling shell refers to the walls, floors, and roof of a building. 
In the High technology scenario NEMS may make available some of the same technologies as in the Base but alter the efficiency and cost values of others. In the Best technologies scenario, only the efficiency and cost values of the best technology available was provided. For example, Figure 9 shows the capital cost and SEER efficiency for central air conditioners available for new construction in 2010. (Replacement air conditioners were given a capital cost of $\$ 1000$ less for the same efficiency.) The least efficient and most efficient equipment were the same in both scenarios, but the middle two air conditioners were more efficient in the High Tech scnenario for roughly the same cost. The Best scenario used only the $\$ 3500$ conditioner with a SEER of 18 . As a consequence, large savings are shown in that scenario.

Figure 9. Central air conditioning capital costs and efficiencies available in 2010

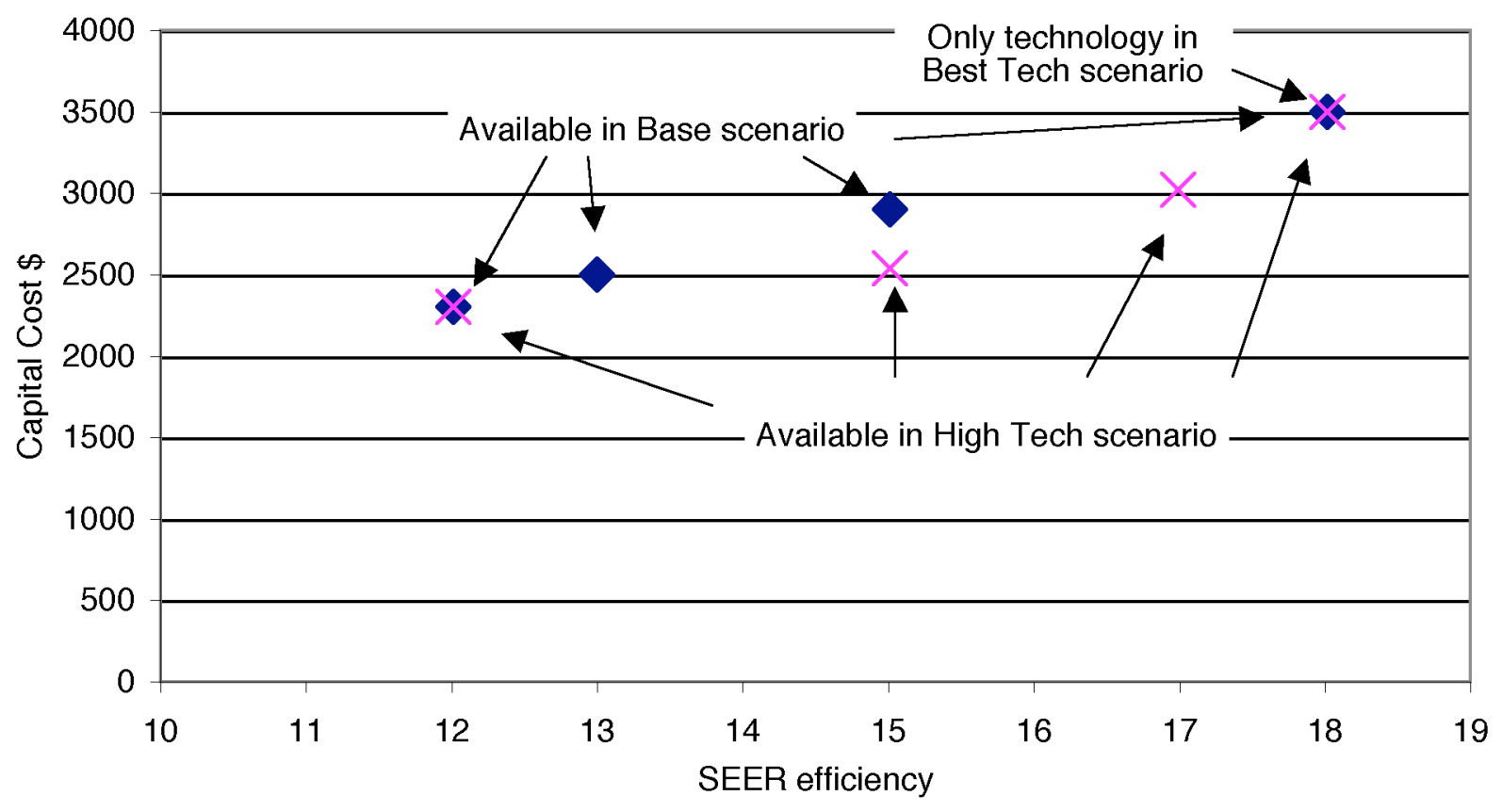

Electric water heaters had small efficiency improvements in three of the five technologies available within the model (Table 9). The first three heaters use only electrical resistance to heat the water, so total efficiency cannot be more than $100 \%$ (energy used/energy in). The last two heaters are heat pump water heaters that include a small heat pump for collecting energy from the air. They can achieve efficiencies much greater than $100 \%$, but are roughly twice as expensive to purchase as ordinary water heaters.

Table 9. Electric water heater costs and efficiencies available in 2010 for Base and High Tech scenarios

\begin{tabular}{|l|r|r|r|r|r|r|}
\hline & \multicolumn{2}{|c|}{ Capital Cost } & Replacement Cost & \multicolumn{2}{c|}{ Efficiency } \\
\cline { 2 - 7 } & Base & High & Base & High & Base & High \\
\hline Water Heater \#1 & 500 & 500 & 260 & 260 & $90 \%$ & $90 \%$ \\
Water Heater \#2 & 500 & 500 & 260 & 260 & $90 \%$ & $92 \%$ \\
Water Heater \#3 & 550 & 550 & 500 & 500 & $95 \%$ & $96 \%$ \\
Water Heater \#4 & 1175 & 1175 & 975 & 975 & $200 \%$ & $200 \%$ \\
Water Heater \#5 & 1100 & 1100 & 975 & 975 & $260 \%$ & $280 \%$ \\
\hline
\end{tabular}




\subsection{ENERGY SAVINGS}

Table 10 shows the amount of energy used in trillion Btu for the various end-use services under the different cases. It also breaks down the usage by fuel. Percentage changes in energy use between the base case and the lowered discount rate case, high technology, and best technology cases show which end-uses were most affected by the policies modeled.

Water heating energy use was the category most affected by the lower discount rates (Figure 10). Energy use dropped by 7.3 TBtu, or 14\%. The savings were largely in electric water heating, where heat pump water heaters became a significant portion of the mix. At low discount rates, the higher cost of the more efficient technologies were more than outweighed by the energy savings. Space cooling, clothes washing, and freezers also saw some improvement.

\section{Figure 10. Residential water heater energy use for different scenarios.}

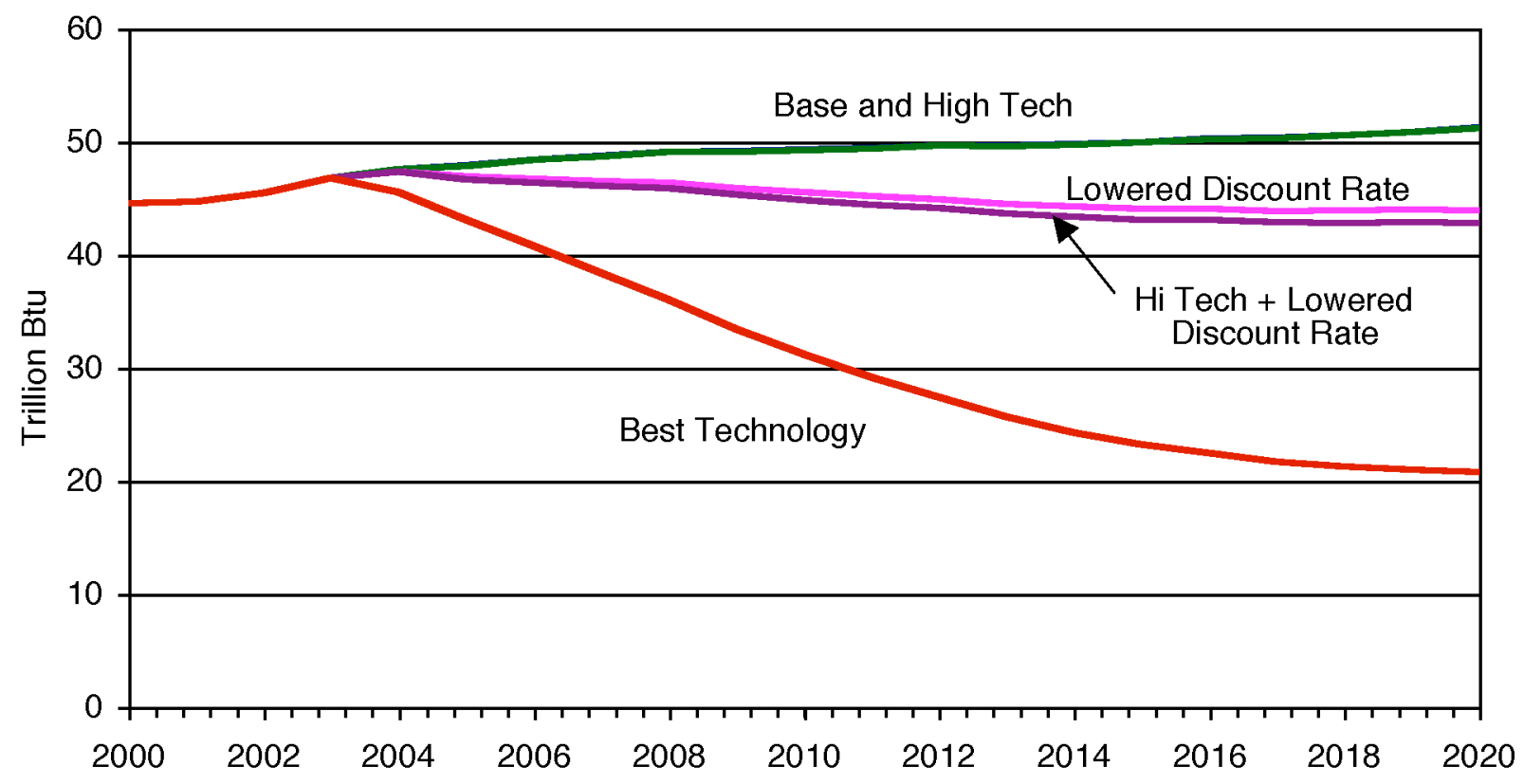

Water heating energy use in the high technology scenario showed very little difference from the base scenario. Energy savings from technology improvements were not sufficient to overcome the high importance on low first cost that the base scenario discount rates indicated. The changes in efficiency from the base scenario were rather slight (Table 9) and with no change in the consumer discount rate there was little change between technologies. When the discount rates were lowered as well as better technologies provided, then some change was observed as more consumers selected the higher efficiency equipment. The Best scenario only made available Water Heater \#5, resulting in the large savings seen in Figure 10. 
Table 10. North Carolina 2020 residential energy use (Trillion Btu)

\begin{tabular}{|c|c|c|c|c|c|c|c|c|c|}
\hline & \multirow[b]{2}{*}{ Base } & \multicolumn{2}{|c|}{$\begin{array}{l}\text { Lowered Dis- } \\
\text { count Rates }\end{array}$} & \multicolumn{2}{|c|}{ High Technology } & \multicolumn{2}{|c|}{$\begin{array}{l}\text { High Technol- } \\
\text { ogy + Lowered } \\
\text { Discount Rates }\end{array}$} & \multicolumn{2}{|c|}{ Best Technology } \\
\hline & & TBtu & change & TBtu & change & TBtu & change & TBtu & change \\
\hline Space Heating & 125.8 & *125.8 & $0.0 \%$ & 121.9 & $-3.1 \%$ & 121.9 & $-3.1 \%$ & 113.0 & $-10.1 \%$ \\
\hline Electric & 22.2 & 22.2 & $0.0 \%$ & 21.1 & $-4.7 \%$ & 21.1 & $-4.7 \%$ & 18.2 & $-17.6 \%$ \\
\hline Gas & 61.1 & 61.1 & $0.0 \%$ & 59.4 & $-2.8 \%$ & 59.4 & $-2.8 \%$ & 54.5 & $-10.9 \%$ \\
\hline Distillate & 12.7 & 12.7 & $0.0 \%$ & 12.4 & $-2.3 \%$ & 12.4 & $-2.3 \%$ & 12.2 & $-4.0 \%$ \\
\hline LPG & 8.8 & 8.8 & $0.0 \%$ & 8.5 & $-2.8 \%$ & 8.5 & $-2.8 \%$ & 8.3 & $-5.9 \%$ \\
\hline Other fossil & 8.9 & 8.9 & $0.0 \%$ & 8.7 & $-2.2 \%$ & 8.7 & $-2.2 \%$ & 8.4 & $-5.1 \%$ \\
\hline Wood & 9.7 & 9.7 & $0.0 \%$ & 9.4 & $-3.2 \%$ & 9.4 & $-3.2 \%$ & 9.4 & $-2.8 \%$ \\
\hline Other renew & 2.4 & 2.4 & $0.0 \%$ & 2.3 & $-3.6 \%$ & 2.3 & $-3.6 \%$ & 2.0 & $-17.8 \%$ \\
\hline Space Cooling & 32.7 & 32.2 & $-1.6 \%$ & 31.2 & $-4.6 \%$ & 30.6 & $-6.4 \%$ & 24.1 & $-26.5 \%$ \\
\hline Electric & 32.7 & 32.2 & $-1.6 \%$ & 31.2 & $-4.6 \%$ & 30.6 & $-6.4 \%$ & 24.1 & $-26.5 \%$ \\
\hline Gas & 0.0 & 0.0 & $0.0 \%$ & 0.0 & $25.3 \%$ & 0.0 & $24.1 \%$ & 0.0 & $19.2 \%$ \\
\hline Water Heating & 51.2 & 43.9 & $-14.3 \%$ & 51.2 & $0.0 \%$ & 42.8 & $-16.5 \%$ & 20.8 & $-59.3 \%$ \\
\hline Electric & 23.6 & 16.4 & $-30.3 \%$ & 23.2 & $-1.6 \%$ & 15.3 & $-35.3 \%$ & 8.5 & $-64.0 \%$ \\
\hline Gas & 25.7 & 25.5 & $-0.5 \%$ & 26.0 & $1.4 \%$ & 25.7 & $0.1 \%$ & 11.2 & $-56.3 \%$ \\
\hline Distillate & 0.4 & 0.4 & $-3.9 \%$ & 0.4 & $0.0 \%$ & 0.4 & $-3.9 \%$ & 0.4 & $-10.2 \%$ \\
\hline LPG & 1.5 & 1.5 & $-2.7 \%$ & 1.5 & $-0.3 \%$ & 1.4 & $-6.4 \%$ & 0.7 & $-53.9 \%$ \\
\hline Cooking & 10.1 & *10.1 & $0.0 \%$ & 10.1 & $0.2 \%$ & 10.1 & $0.2 \%$ & 10.2 & $1.1 \%$ \\
\hline Electric & 5.2 & 5.2 & $0.0 \%$ & 5.2 & $-0.2 \%$ & 5.2 & $-0.2 \%$ & 5.2 & $-0.9 \%$ \\
\hline Gas & 4.0 & 4.0 & $0.0 \%$ & 4.0 & $0.8 \%$ & 4.0 & $0.8 \%$ & 4.1 & $3.0 \%$ \\
\hline LPG & 0.9 & 0.9 & $0.0 \%$ & 0.9 & $-0.3 \%$ & 0.9 & $-0.3 \%$ & 0.9 & $5.0 \%$ \\
\hline Clothes Wash & 1.0 & 0.9 & $-5.6 \%$ & 1.0 & $0.0 \%$ & 0.9 & $-5.6 \%$ & 0.9 & $-5.6 \%$ \\
\hline Clothes Drying & 12.2 & 12.2 & $0.0 \%$ & 12.2 & $0.0 \%$ & 12.2 & $0.1 \%$ & 12.2 & $0.0 \%$ \\
\hline Electric & 10.9 & 10.9 & $0.0 \%$ & 10.9 & $0.0 \%$ & 10.9 & $0.1 \%$ & 10.9 & $-0.1 \%$ \\
\hline Gas & 1.3 & 1.3 & $0.0 \%$ & 1.3 & $0.0 \%$ & 1.3 & $-0.1 \%$ & 1.3 & $0.8 \%$ \\
\hline Refrigeration & 11.4 & 11.4 & $0.0 \%$ & 11.4 & $-0.3 \%$ & 11.4 & $-0.4 \%$ & 10.4 & $-8.5 \%$ \\
\hline Freezers & 3.5 & 3.5 & $-0.6 \%$ & 3.5 & $0.0 \%$ & 3.5 & $-0.6 \%$ & 3.3 & $-7.5 \%$ \\
\hline Lighting & 33.9 & *33.9 & $0.0 \%$ & 27.6 & $-18.6 \%$ & 27.6 & $-18.7 \%$ & 21.1 & $-37.6 \%$ \\
\hline Other & 100.2 & *100.2 & $0.0 \%$ & 97.3 & $-2.9 \%$ & 97.3 & $-2.9 \%$ & 96.5 & $-3.7 \%$ \\
\hline Electric & 84.4 & 84.4 & $0.0 \%$ & 81.6 & $-3.4 \%$ & 81.6 & $-3.4 \%$ & 80.7 & $-4.4 \%$ \\
\hline Gas & 2.4 & 2.4 & $0.0 \%$ & 2.4 & $0.0 \%$ & 2.4 & $0.0 \%$ & 2.4 & $0.8 \%$ \\
\hline LPG & 13.3 & 13.3 & $0.0 \%$ & 13.3 & $0.0 \%$ & 13.3 & $0.0 \%$ & 13.3 & $0.0 \%$ \\
\hline Total & 382.1 & 374.2 & $-2.1 \%$ & 367.5 & $-3.8 \%$ & 358.4 & $-6.2 \%$ & 312.7 & $-18.2 \%$ \\
\hline Electric & 228.9 & 221.1 & $-3.4 \%$ & 216.7 & $-5.3 \%$ & 208.1 & $-9.1 \%$ & 183.4 & $-19.9 \%$ \\
\hline Gas & 94.5 & 94.4 & $-0.1 \%$ & 93.2 & $-1.4 \%$ & 92.9 & $-1.8 \%$ & 73.6 & $-22.2 \%$ \\
\hline Distillate & 13.2 & 13.2 & $-0.1 \%$ & 12.9 & $-2.2 \%$ & 12.9 & $-2.4 \%$ & 12.6 & $-4.3 \%$ \\
\hline LPG & 24.5 & 24.5 & $-0.2 \%$ & 24.3 & $-1.0 \%$ & 24.2 & $-1.4 \%$ & 23.2 & $-5.3 \%$ \\
\hline Other fossil & 8.9 & 8.9 & $0.0 \%$ & 8.7 & $-2.2 \%$ & 8.7 & $-2.2 \%$ & 8.4 & $-5.1 \%$ \\
\hline Renewable & 12.1 & 12.1 & $0.0 \%$ & 11.7 & $-3.3 \%$ & 11.7 & $-3.3 \%$ & 11.4 & $-5.8 \%$ \\
\hline
\end{tabular}

* Space heating, cooking, lighting, and other did not have discount rate changes

Bold numbers indicate end-uses studied with significant savings 
Space cooling did show differences both from changes in discount rates and changes in technology (Table 10). Combining both discount rate reductions and high technology compounded the savings. Space cooling can come from several different technology types: room air conditioners, central air conditioners, and heat pumps. Furthermore, heat pumps can be fueled by electricity, gas, or geothermal sources. Because heat pumps provide both heat and cooling, NEMS calculates the cost of providing both services using a variety of technologies before allocating market share. With the increase of SEER values for several of the systems (Figure 9), the cost savings were sufficient to encourage higher-efficiency equipment purchases, despite higher costs. Similarly, lowering the discount rate encouraged some consumers to select a more efficient piece of equipment.

Lighting and Other end-use categories showed significant improvements with higher technology but not in the lowered discount rate scenario. This is simply because these two categories are modeled within NEMS differently than the other end-uses. Lighting technology parameters (cost and efficiency for different technologies) are assigned within the code and the implicit discount rate is fixed for the entire study period. The high and best technology scenarios increased the penetration of efficient lighting by gradually lowering the capital cost for efficient lighting post2003. The "other" categories of small motors, heating elements, and other electronics were improved through modification of their growth rates based on external calculations by EIA.

Total energy savings with just the discount rates lowered were $2.1 \%$ from the Base case while total electricity use dropped 3.4\% (Table 10). The savings of 7.8 trillion Btus of electricity equals $2280 \mathrm{GWh}$. At $7.6 \notin / \mathrm{kWh}$ (the 2020 value in $2001 \$$ ) this represents savings of $\$ 173$ million per year by 2020. The amount of electricity saved represents about the output of a $325 \mathrm{MW}$ power plant (Table 11). Under the High Technology or other scenarios, the savings would be even higher.

Table 11. Value of electricity saved in 2020 in Residential sector under different scenarios

\begin{tabular}{|l|cccc|}
\hline & & \multicolumn{3}{c|}{$\begin{array}{c}\text { High Tech- } \\
\text { nology + }\end{array}$} \\
& $\begin{array}{c}\text { Lowered Dis- } \\
\text { count Rates }\end{array}$ & $\begin{array}{c}\text { High } \\
\text { Technology } \\
\text { count Rates }\end{array}$ & $\begin{array}{c}\text { Best } \\
\text { Technology }\end{array}$ \\
\hline Energy saved, TBtu & 7.9 & 14.6 & 23.7 & 69.4 \\
Electricity saved, TBtu & 7.8 & 12.2 & 20.8 & 45.5 \\
Value of electricity saved, M\$ & 173 & 271 & 463 & 1013 \\
Displaced capacity ${ }^{\mathrm{a}}, \mathrm{MW}$ & 325 & 508 & 869 & 1902 \\
\hline
\end{tabular}

${ }^{a}$ Size of a power plant operating at $80 \%$ capacity factor that would generate the amount of electricity saved. Actual capacity could be much higher if electricity savings are from a smaller fraction of the year. 


\section{COMMERCIAL ENERGY ANALYSIS}

\subsection{REFERENCE ENERGY USE}

The commercial end-use sector used 191 TBtus in 1999, which represents 11\% of total end-use consumption (Table 1). This is the smallest of the four end-use sectors. It can be further separated by the type of commercial activity (assuming the mix of sectors for North Carolina is the same as the South Atlantic region) (Figure 11). The large, non-building-specific portion represents energy use for distributed generation, district heating, and other categories not calculated specifically to the a building type. The largest building-specific energy use has to do with mercantile/service businesses.

Figure 11. North Carolina commercial energy use in Base scenario

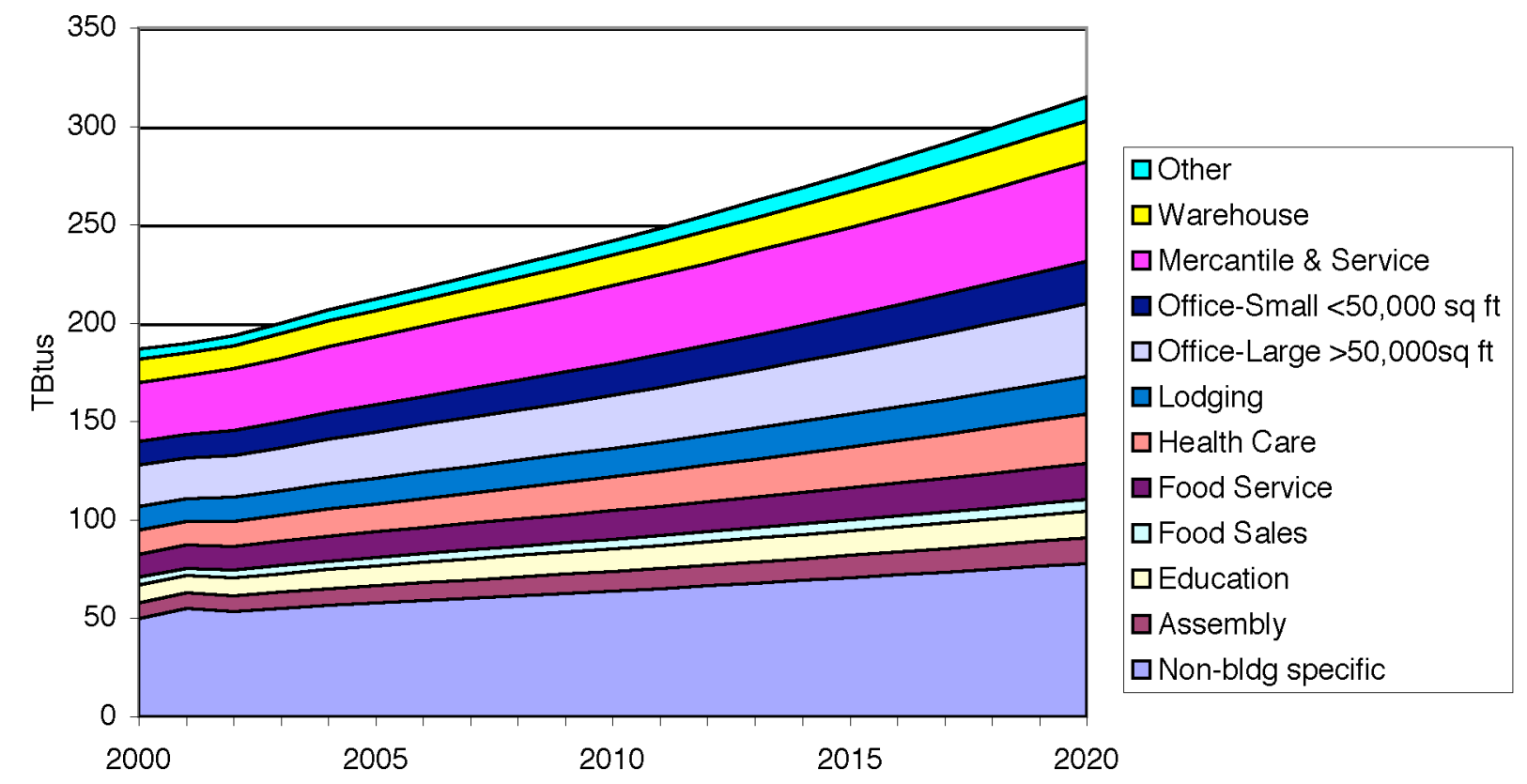

As with the residential sector, space heating makes up the bulk of energy use in the sector (Figure 12). There is also a large "Other" category. A large portion of this is the energy used in cogeneration, where the energy from natural gas is used both for heat or process steam as well as to make electricity for use by the business. Lighting is also a large end-use, with water heating being the next largest.

Of the commercial electricity use, lighting is the largest end-use, representing $38 \%$ of total electricity in 2000 (Figure 13). The Other category within electricity contains transformers, traffic lights, exit signs, automated teller machines, telecommunications equipment, medical equipment, and other unidentified end-uses. It also includes an adjustment term to ensure that the total commercial sector energy use adds up to the totals reported in EIA's State Energy Data Report. 
Figure 12. North Carolina commercial energy use in Base scenario

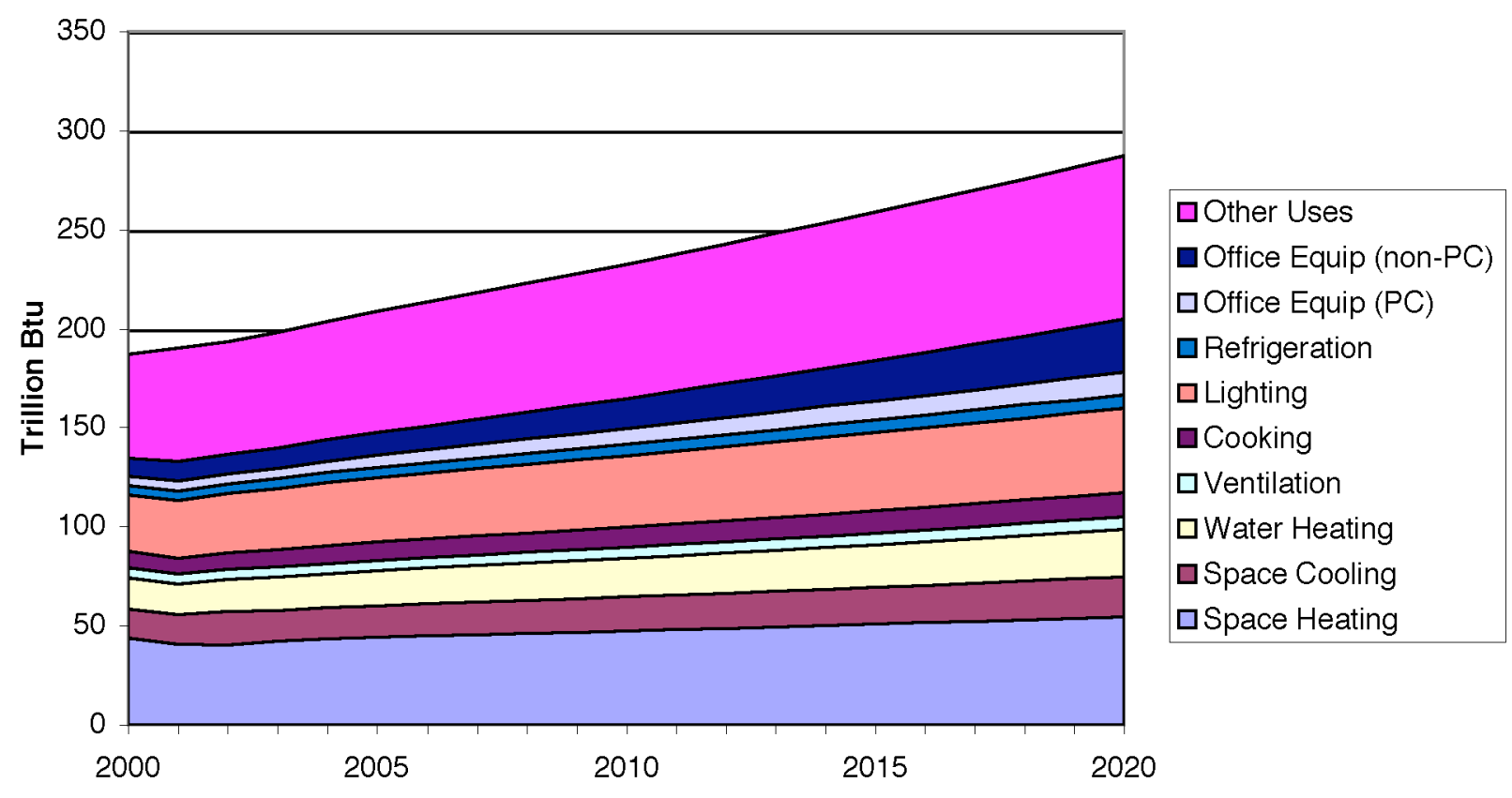

Figure 13. North Carolina commercial electricity use in Base scenario

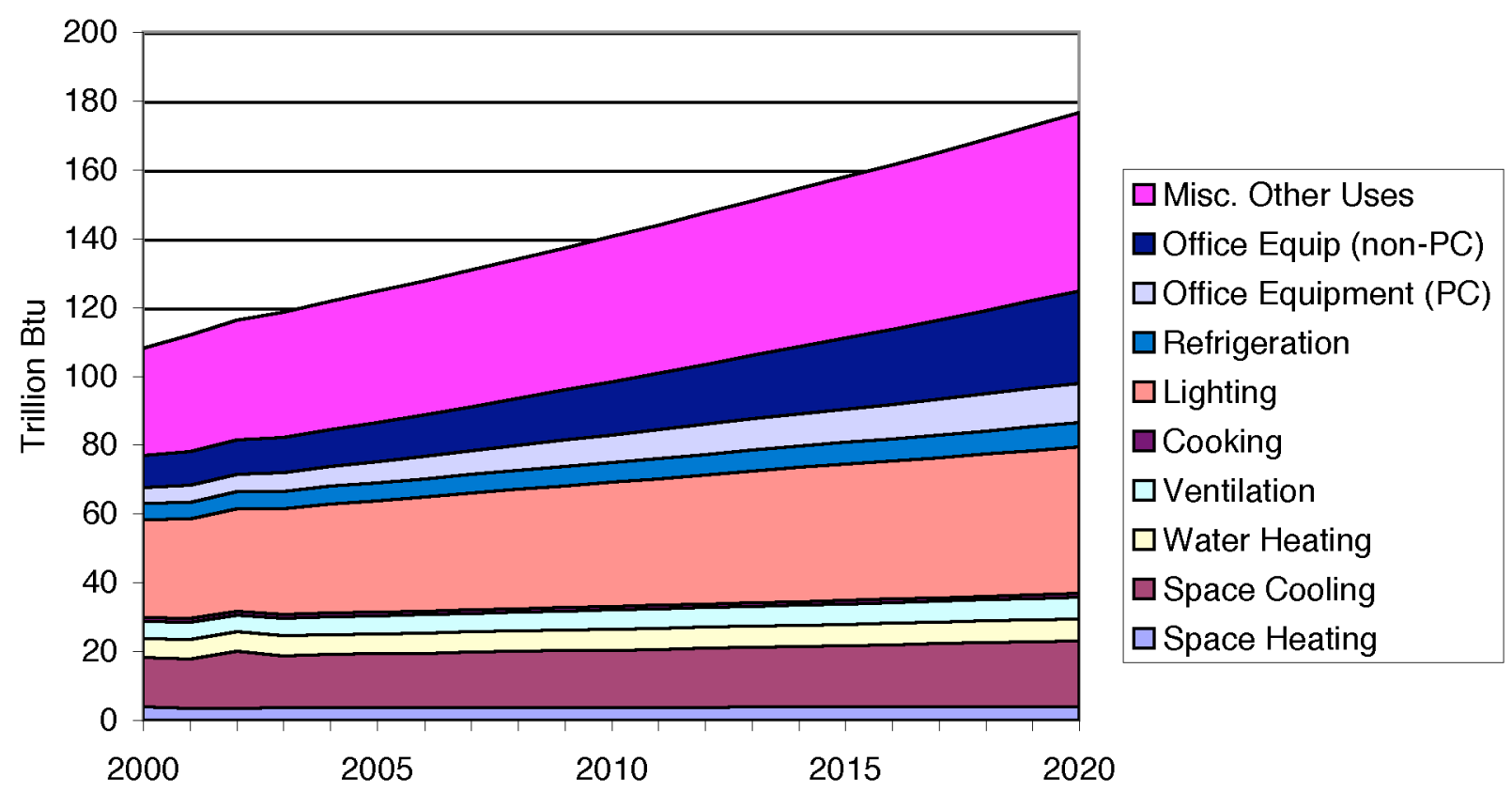

A more detailed breakdown of energy use by end-use and fuel is shown in Table 12 . 
Table 12. 2000 North Carolina commercial sector energy use. Green rows show totals for each major end-use; indented rows below each shaded row show the break-down by fuel.

\begin{tabular}{|c|c|c|c|c|c|c|}
\hline Total by End-Use & $\begin{array}{c}2000 \\
\text { Energy } \\
\text { Use, TBtu }\end{array}$ & $\begin{array}{c}\% \text { of Total } \\
\text { Energy }\end{array}$ & $\begin{array}{l}\% \text { of To- } \\
\text { tal Gas }\end{array}$ & $\begin{array}{c}\% \text { of Total } \\
\text { Electric }\end{array}$ & $\begin{array}{l}\% \text { of Each } \\
\text { End-use }\end{array}$ & $\begin{array}{c}\text { Annual } \\
\text { Growth Rate } \\
2000-2020\end{array}$ \\
\hline Space Heating & 43.7 & $23 \%$ & & & & $1.1 \%$ \\
\hline Electric & 3.8 & & & $4 \%$ & $9 \%$ & $0.1 \%$ \\
\hline Gas & 18.4 & & $38 \%$ & & $42 \%$ & $1.5 \%$ \\
\hline Distillate & 5.0 & & & & $11 \%$ & $2.8 \%$ \\
\hline Other fossil ${ }^{\mathrm{a}}$ & 12.3 & & & & $28 \%$ & $0.2 \%$ \\
\hline Wood & 4.0 & & & & $9 \%$ & $0.0 \%$ \\
\hline Other renew ${ }^{b}$ & 0.2 & & & & $0 \%$ & $1.7 \%$ \\
\hline Space Cooling & 14.7 & $8 \%$ & & & & $1.6 \%$ \\
\hline Electric & 14.3 & & & $13 \%$ & $98 \%$ & $1.5 \%$ \\
\hline Gas & 0.4 & & $1 \%$ & & $2 \%$ & $4.5 \%$ \\
\hline Water Heating & 15.8 & $8 \%$ & & & & $2.1 \%$ \\
\hline Electric & 5.7 & & & $5 \%$ & $36 \%$ & $0.6 \%$ \\
\hline Gas & 8.4 & & $17 \%$ & & $53 \%$ & $3.0 \%$ \\
\hline Distillate & 1.8 & & & & $11 \%$ & $1.2 \%$ \\
\hline Ventilation & 5.0 & $3 \%$ & & & & $1.2 \%$ \\
\hline Cooking & 8.2 & $4 \%$ & & & & $2.1 \%$ \\
\hline Electric & 1.1 & & & $1 \%$ & $13 \%$ & $-0.1 \%$ \\
\hline Gas & 7.1 & & $15 \%$ & & $87 \%$ & $2.3 \%$ \\
\hline Lighting & 28.4 & $15 \%$ & & & & $2.0 \%$ \\
\hline Refrigeration & 4.7 & $3 \%$ & & & & $2.0 \%$ \\
\hline Office Equip (PC) & 4.7 & $3 \%$ & & & & $4.6 \%$ \\
\hline Office Equip (non-PC) & 9.3 & $5 \%$ & & & & $5.5 \%$ \\
\hline Other Uses & 52.6 & $28 \%$ & & & & $2.3 \%$ \\
\hline Electric $^{c}$ & 31.1 & & & $29 \%$ & $59 \%$ & $2.6 \%$ \\
\hline $\operatorname{Gas}^{d}$ & 14.7 & & $30 \%$ & & $28 \%$ & $2.5 \%$ \\
\hline Distillate $^{d}$ & 6.8 & & & & $13 \%$ & $-0.3 \%$ \\
\hline Total & 187.0 & $100 \%$ & & & & $2.2 \%$ \\
\hline Electric & 108.0 & $58 \%$ & \multirow{5}{*}{\multicolumn{2}{|c|}{$\begin{array}{l}\% \text { of total } \\
\text { commercial } \\
\text { energy use }\end{array}$}} & & $2.5 \%$ \\
\hline Gas & 49.0 & $26 \%$ & & & & $2.3 \%$ \\
\hline Distillate & 13.6 & $7 \%$ & & & & $1.2 \%$ \\
\hline Other fossil & 12.3 & $7 \%$ & & & & $0.2 \%$ \\
\hline Renewable & 4.2 & $0 \%$ & & & & $0.1 \%$ \\
\hline
\end{tabular}

${ }^{\mathrm{a}}$ Includes LPG, coal, and kerosene

${ }^{\mathrm{b}}$ Includes solar thermal and geothermal

${ }^{\mathrm{c}}$ Includes transformers, traffic lights, exit signs, automated teller machines, telecommunications equipment, medical equipment, and other unidentified end-uses.

${ }^{\mathrm{d}}$ Includes distributed generation

Commercial energy prices vary somewhat from the Residential sector, most notably higher natural gas prices compared to distillate prices. This causes a shift in fuel usage when discount rates are lowered so that fuel prices play a larger role in the decision (Figure 14). 
Figure 14. Commercial energy prices for the South Atlantic region

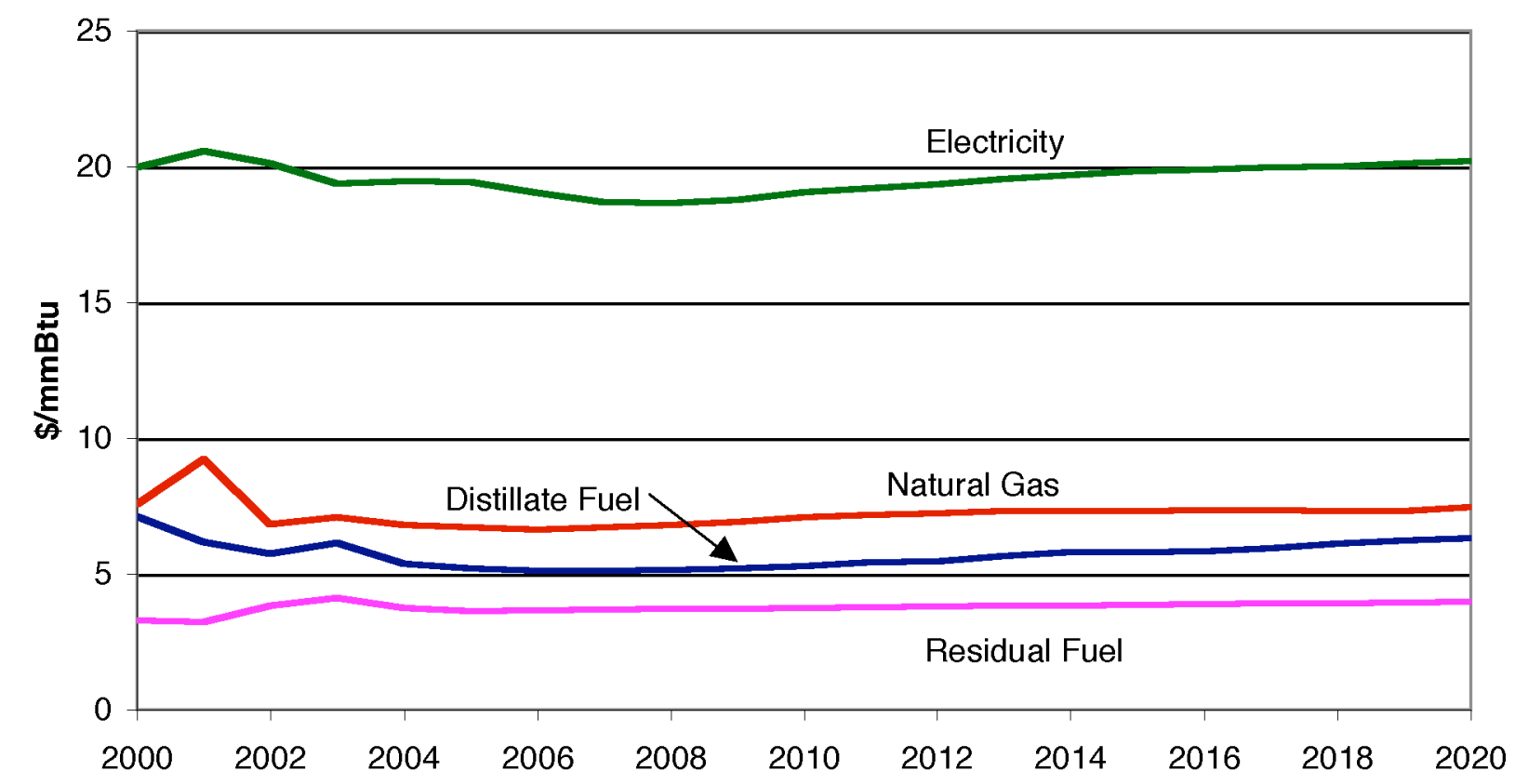

\subsection{IMPROVEMENTS}

As in the Residential sector, four alternative scenarios to the Base were run: lowered discount rate, high technology, lowered rate plus high technology, and best technology. Within NEMS each of the commercial sectors has a range of discount rates, representing the spectrum of preferences for businesses within that sector. Some businesses may have a very short focus or be very risk-averse, leading to a high discount rate. Other firms may be more energy conscious or willing to take risks, leading to a low discount rate. As a consequence a variety of equipment will be purchased for each sector.

As part of the analysis for the CEF study, the various market-related energy efficiency programs were converted to discount rate reductions and applied to the sectors. Lighting, water heating, and the heating, ventilation, and air conditioning (HVAC) end-uses were given different sets of discount rates, based upon the success of market programs.

Table 13 shows the percentage of customers at each of the available discount rates. The AEO2003 used essentially the same mix for all end-uses, with discount rates generally very high. Over one quarter of customers had an equivalent rate of 10 , or $1000 \%$. This says that these customers place essentially no value on ongoing cost savings (one dollar now is equivalent to $\$ 11$ next year.) Rates of 55\% and $153 \%$ also are high enough to make ongoing energy savings a relatively unimportant aspect in the decision process as well. Only eleven percent of customers have a discount rate of $20 \%$ or less.

In the CEF study, all customers had a discount rate of $14 \%$ for their HVAC equipment. This is equivalent to a payback period of five years. Information, loans, or other market programs would 
lower their effective rate to this value. Water heating equipment would be somewhat higher, with $50 \%$ of customers at the $14 \%$ discount rate (5 year payback), and $25 \%$ of customers at $20 \%(3.5$ year payback) and 31\% (2.2 year payback) respectively. Lighting discount rates would be more evenly spread over those available in the model.

Table 13. Percentage of commercial customers at each discount rate for each end-use. In Base scenario most customers are at higher rates.

\begin{tabular}{|cc|cc|cccc|}
\hline \multirow{2}{*}{$\begin{array}{c}\text { Discount } \\
\text { Required }\end{array}$} & $\begin{array}{c}\text { Requack } \\
\text { Pate }\end{array}$ & Bears) & Base scenario & \multicolumn{3}{|c|}{ Lowered Discount Rate scenario } \\
\cline { 3 - 7 } (yearting & All Other & Lighting & $\begin{array}{c}\text { Water } \\
\text { Heating }\end{array}$ & $\begin{array}{c}\text { HVAC + Re- } \\
\text { frigeration }\end{array}$ & Cooking \\
\hline $1000 \%$ & 0.1 & $27 \%$ & $27 \%$ & $15 \%$ & $0 \%$ & $0 \%$ & $27 \%$ \\
$153 \%$ & 0.5 & $25 \%$ & $25 \%$ & $15 \%$ & $0 \%$ & $0 \%$ & $25 \%$ \\
$55 \%$ & 1.3 & $20 \%$ & $20 \%$ & $20 \%$ & $0 \%$ & $0 \%$ & $20 \%$ \\
$31 \%$ & 2.2 & $16 \%$ & $16 \%$ & $20 \%$ & $25 \%$ & $0 \%$ & $16 \%$ \\
$20 \%$ & 3.5 & $9 \%$ & $10 \%$ & $15 \%$ & $25 \%$ & $0 \%$ & $10 \%$ \\
$14 \%$ & 5.0 & $2 \%$ & $1 \%$ & $15 \%$ & $50 \%$ & $100 \%$ & $1 \%$ \\
\hline
\end{tabular}

As a consequence of these lower rates, efficiency of equipment increases in most end-uses (Table 14). Natural gas cooling increases most significantly as better chillers and heat pumps are selected. Water heating improves as heat pump water heaters penetrate the market, raising efficiencies above 1.0 .

Table 14. Commercial equipment efficiency improvements for new equipment with lowered discount rates (Btu out/Btu in)

\begin{tabular}{|c|c|c|c|c|c|c|c|}
\hline & 2000 & \multicolumn{3}{|c|}{2010} & \multicolumn{3}{|c|}{2020} \\
\hline & Base & Base & $\begin{array}{l}\text { Lower } \\
\text { Rate }\end{array}$ & $\begin{array}{l}\% \text { over } \\
\text { Base }\end{array}$ & Base & $\begin{array}{l}\text { Lower } \\
\text { Rate }\end{array}$ & $\begin{array}{l}\% \text { over } \\
\text { Base }\end{array}$ \\
\hline \multicolumn{8}{|l|}{ Space Heating } \\
\hline Electricity & 1.11 & 1.07 & 1.19 & $11 \%$ & 1.06 & 1.18 & $11 \%$ \\
\hline Natural Gas & 0.76 & 0.79 & 0.81 & $3 \%$ & 0.79 & 0.81 & $3 \%$ \\
\hline Distillate & 0.79 & 0.79 & 0.8 & $1 \%$ & 0.79 & 0.81 & $3 \%$ \\
\hline \multicolumn{8}{|l|}{ Space Cooling } \\
\hline Electricity & 3.34 & 3.6 & 3.81 & $6 \%$ & 3.76 & 4.11 & $9 \%$ \\
\hline Natural Gas & 1.34 & 1.18 & 2.05 & $74 \%$ & 1.2 & 2.16 & $80 \%$ \\
\hline \multicolumn{8}{|l|}{ Water Heating } \\
\hline Electricity & 0.99 & 0.99 & 1.02 & $3 \%$ & 0.98 & 1.05 & $7 \%$ \\
\hline Natural Gas & 0.83 & 0.83 & 0.92 & $11 \%$ & 0.84 & 0.93 & $11 \%$ \\
\hline Distillate & 0.78 & 0.78 & 0.78 & $0 \%$ & 0.78 & 0.78 & $0 \%$ \\
\hline \multicolumn{8}{|c|}{ Ventilation (cfm per Btu) } \\
\hline Electricity & 0.41 & 0.43 & 0.56 & $30 \%$ & 0.47 & 0.62 & $32 \%$ \\
\hline \multicolumn{8}{|c|}{ Lighting Efficacy (lumens per watt) } \\
\hline $\begin{array}{r}\text { Electricity } \\
\text { Refrigeration }\end{array}$ & 41.67 & 42.9 & 52.62 & $23 \%$ & 44.49 & 61.54 & $38 \%$ \\
\hline Electricity & 1.37 & 1.41 & 1.54 & $9 \%$ & 1.4 & 1.53 & $9 \%$ \\
\hline
\end{tabular}




\subsection{ENERGY SAVINGS}

As a consequence of lower discount rates for consumers, energy use by 2020 in the commercial sector drops 3.8\% from the amount in the Base case (Table 15). Electricity use drops 6.7\%. The major savings areas are in ventilation (15\%), lighting $(21 \%)$, and refrigeration $(7.5 \%)$. In terms of largest amount of energy saved, the major end-use is in gas space heating, followed by electric lighting.

Table 15. North Carolina 2020 commercial energy use from Base, Lowered Discount Rate, High Technology and Best Technology cases (trillion Btu)

\begin{tabular}{|c|c|c|c|c|c|c|c|c|c|}
\hline & \multirow[b]{2}{*}{ Base } & \multicolumn{2}{|c|}{$\begin{array}{l}\text { Lowered Dis- } \\
\text { count Rates }\end{array}$} & \multicolumn{2}{|c|}{ High Technology } & \multicolumn{2}{|c|}{$\begin{array}{l}\text { High Technol- } \\
\text { ogy + Lowered } \\
\text { Discount Rates }\end{array}$} & \multicolumn{2}{|c|}{ Best Technology } \\
\hline & & TBtu & change & TBtu & change & TBtu & change & TBtu & change \\
\hline Space Heating & 54.4 & 55.8 & $3 \%$ & 53.8 & $-1 \%$ & 54.3 & $0 \%$ & 52.1 & $-4 \%$ \\
\hline Electric & 3.9 & 3.5 & $-9 \%$ & 3.8 & $-2 \%$ & 3.3 & $-15 \%$ & 3.8 & $-1 \%$ \\
\hline Gas & 24.9 & 21.2 & $-15 \%$ & 24.5 & $-1 \%$ & 20.7 & $-17 \%$ & 23.7 & $-5 \%$ \\
\hline Distillate & 8.6 & 13.7 & $58 \%$ & 8.4 & $-2 \%$ & 13.2 & $53 \%$ & 7.6 & $-12 \%$ \\
\hline Other fossil & 12.8 & 12.8 & $0 \%$ & 12.8 & $0 \%$ & 12.8 & $0 \%$ & 12.8 & $0 \%$ \\
\hline Wood & 4.0 & 4.0 & $0 \%$ & 4.0 & $0 \%$ & 4.0 & $0 \%$ & 4.0 & $0 \%$ \\
\hline Other renew & 0.3 & 0.6 & $117 \%$ & 0.2 & $-17 \%$ & 0.3 & $6 \%$ & 0.2 & $-17 \%$ \\
\hline Space Cooling & 20.1 & 19.2 & $-5 \%$ & 19.6 & $-2 \%$ & 18.8 & $-6 \%$ & 16.1 & $-20 \%$ \\
\hline Electric & 19.2 & 18.5 & $-4 \%$ & 18.8 & $-3 \%$ & 18.1 & $-6 \%$ & 15.6 & $-19 \%$ \\
\hline Gas & 0.9 & 0.7 & $-18 \%$ & 0.9 & $-2 \%$ & 0.7 & $-18 \%$ & 0.5 & $-42 \%$ \\
\hline Water Heating & 23.8 & 23.0 & $-3 \%$ & 23.8 & $0 \%$ & 22.9 & $-4 \%$ & 23.1 & $-3 \%$ \\
\hline Electric & 6.4 & 6.1 & $-4 \%$ & 6.3 & $0 \%$ & 6.1 & $-5 \%$ & 6.4 & $1 \%$ \\
\hline Gas & 15.2 & 14.0 & $-8 \%$ & 15.2 & $0 \%$ & 14.0 & $-8 \%$ & 14.4 & $-5 \%$ \\
\hline Distillate & 2.3 & 2.8 & $24 \%$ & 2.3 & $0 \%$ & 2.8 & $24 \%$ & 2.2 & $-4 \%$ \\
\hline Ventilation & 6.3 & 5.3 & $-15 \%$ & 6.2 & $-1 \%$ & 5.3 & $-17 \%$ & 5.3 & $-17 \%$ \\
\hline Cooking & 12.4 & 12.2 & $-1 \%$ & 12.4 & $0 \%$ & 12.2 & $-1 \%$ & 11.3 & $-9 \%$ \\
\hline Electric & 1.1 & 1.1 & $0 \%$ & 1.1 & $0 \%$ & 1.0 & $-1 \%$ & 1.0 & $-5 \%$ \\
\hline Gas & 11.3 & 11.2 & $-1 \%$ & 11.3 & $0 \%$ & 11.2 & $-1 \%$ & 10.3 & $-9 \%$ \\
\hline Lighting & 42.6 & 33.7 & $-21 \%$ & 40.6 & $-5 \%$ & 30.9 & $-27 \%$ & 23.7 & $-44 \%$ \\
\hline Refrigeration & 7.0 & 6.5 & $-8 \%$ & 7.0 & $-1 \%$ & 6.3 & $-10 \%$ & 6.2 & $-12 \%$ \\
\hline Office Equip, PC & 11.5 & 11.5 & $0 \%$ & 11.4 & $-1 \%$ & 11.4 & $-1 \%$ & 9.8 & $-15 \%$ \\
\hline Office Equip, non-PC & 26.9 & 26.8 & $0 \%$ & 26.1 & $-3 \%$ & 26.1 & $-3 \%$ & 24.7 & $-8 \%$ \\
\hline Other Uses & 82.3 & 82.3 & $0 \%$ & 82.5 & $0 \%$ & 82.5 & $0 \%$ & 83.5 & $1 \%$ \\
\hline Electric & 51.7 & 51.7 & $0 \%$ & 51.8 & $0 \%$ & 51.8 & $0 \%$ & 51.9 & $0 \%$ \\
\hline Gas & 24.2 & 24.2 & $0 \%$ & 24.3 & $0 \%$ & 24.3 & $0 \%$ & 25.2 & $4 \%$ \\
\hline Distillate & 6.4 & 6.4 & $0 \%$ & 6.4 & $0 \%$ & 6.4 & $0 \%$ & 6.4 & $1 \%$ \\
\hline Total & 287.3 & 276.4 & $-3.8 \%$ & 283.4 & $-1 \%$ & 270.8 & $-6 \%$ & 255.7 & $-11 \%$ \\
\hline Electric & 176.5 & 164.7 & $-6.7 \%$ & 172.9 & $-2 \%$ & 160.2 & $-9 \%$ & 148.1 & $-16 \%$ \\
\hline Gas & 76.4 & 71.3 & $-6.7 \%$ & 76.2 & $0 \%$ & 70.9 & $-7 \%$ & 74.1 & $-3 \%$ \\
\hline Distillate & 17.3 & 22.9 & $32.3 \%$ & 17.1 & $-1 \%$ & 22.4 & $30 \%$ & 16.2 & $-6 \%$ \\
\hline Other fossil & 12.8 & 12.8 & $0.1 \%$ & 12.8 & $0 \%$ & 12.8 & $0 \%$ & 12.8 & $0 \%$ \\
\hline Renewable & 4.3 & 4.6 & $7.5 \%$ & 4.4 & $1 \%$ & 4.4 & $3 \%$ & 4.4 & $2 \%$ \\
\hline
\end{tabular}

Bold numbers indicate end-uses studied with significant savings 
An unusual result from lowering the discount rates was the increase in use of distillate fuel at the expense of natural gas, especially for space heating. While gas use declined by 3.7 TBtu, distillate use increased by 5.0 TBtu. There may have also been some switching from electricity to distillate, though this is less apparent. Since distillate-fueled technologies are somewhat lower efficiency, the net effect was an increase in energy use. There was also an increase in renewable fuels use, notably solar thermal systems increased by $54 \%$ from 0.28 to 0.6 TBtu. Because NEMS produces values for the South Atlantic region rather than North Carolina, it may be that the increase in distillate fuel and solar thermal are driven more by conditions (e.g., prices, availability) in other states in the region such as Florida (which has a high proportional use of distillate fuel and solar thermal.)

The High Technology scenario shows little change in most of the end-use categories (Table 15). Lighting shows one of the larger impacts (Figure 15). This implies that improvements in technology alone, without programs to lower the resistance to these technologies, will not greatly impact the amount of energy use. At the high discount rates in the base and high technology scenarios, consumers will generally make their decisions more on first cost than on the long-term energy savings. When both high technology and lowered discount rates are used, the savings from each are compounded. Finally, when consumers are only allowed to select the best technologies, energy savings improve much more. The technologies with the most significant improvement were cooling, ventilation, lighting, refrigeration, and office equipment.

\section{Figure 15. Commercial energy use for lighting for different scenarios}

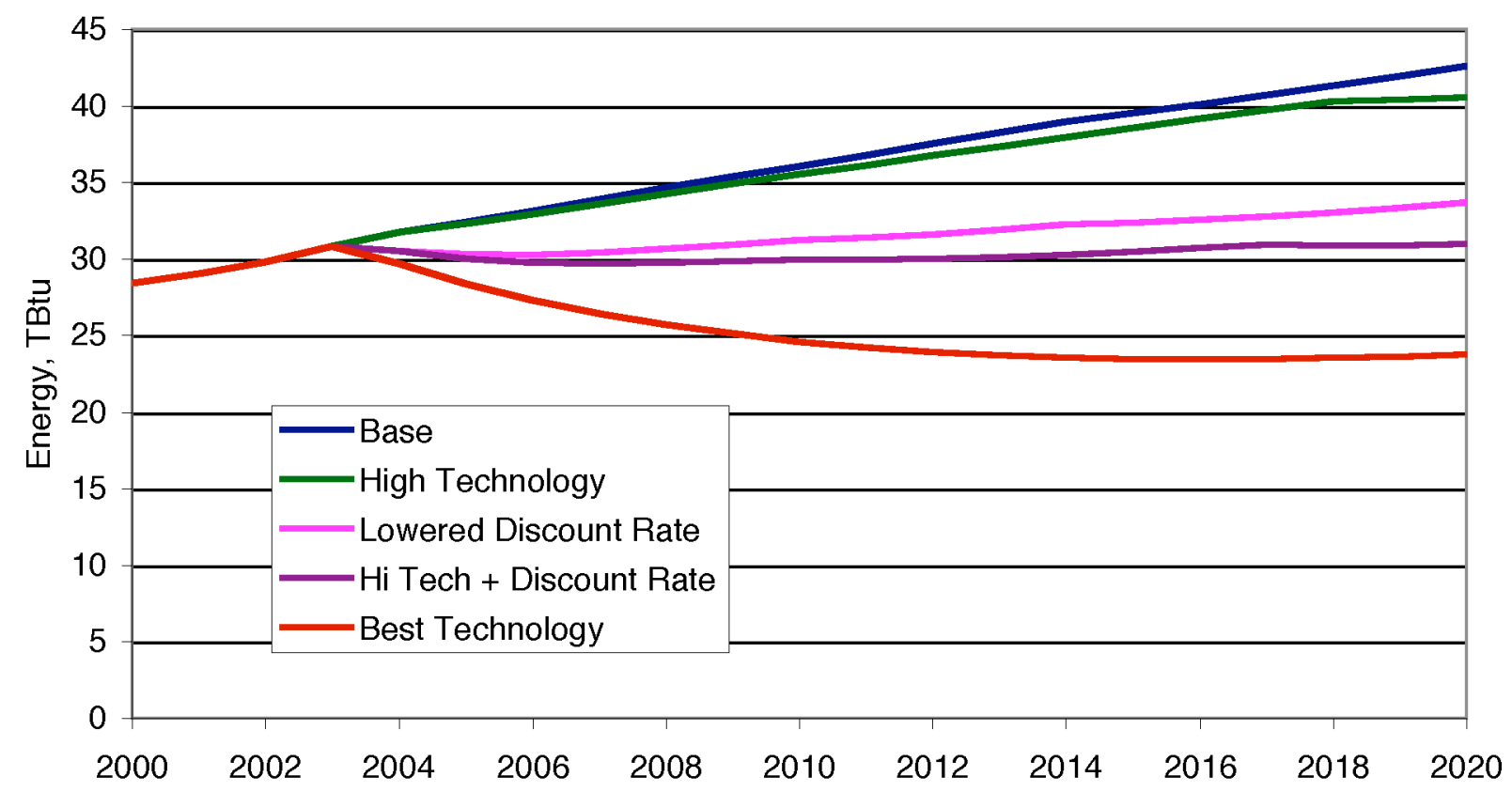

Electrical savings of 11.7 TBtu in the Lowered Discount Rate scenario translates into 3.44 TWh. Using an electrical price of $6.9 \mathrm{k} / \mathrm{kWh}$ (the regional Commercial price from the AEO2003) gives a savings of $\$ 237$ million from electricity savings (Table 16). Converting the electricity savings to the equivalent amount from a power plant (running at $80 \%$ capacity factor) means that the equivalent of a $490 \mathrm{MW}$ plant would not need to be built for the state's commercial demands. 
The High Technology scenario does not save as much electricity, but with both high technology and lowered discount rates, the state would save $\$ 328$ million per year by 2020 . If the best technology were the only technology used, then the equivalent of an 1,184 MW power plant would be displaced.

Table 16. Value of electricity saved in 2020 under different scenarios

\begin{tabular}{|l|cccc|}
\hline & & \multicolumn{3}{c|}{$\begin{array}{c}\text { High Tech- } \\
\text { nology + } \\
\text { Lowered Dis- }\end{array}$} \\
& $\begin{array}{c}\text { Lowered Dis- } \\
\text { count Rates }\end{array}$ & $\begin{array}{c}\text { High } \\
\text { Technology } \\
\text { count Rates }\end{array}$ & $\begin{array}{c}\text { Best } \\
\text { Technology }\end{array}$ \\
\hline Energy saved, TBtu & 10.9 & 3.9 & 16.5 & 31.6 \\
Electricity saved, TBtu & 11.7 & 3.5 & 16.3 & 28.3 \\
Value of electricity saved, M\$ & 237 & 72 & 328 & 572 \\
Displaced capacity ${ }^{\mathrm{a}}, \mathrm{MW}$ & 491 & 148 & 680 & 1184 \\
\hline
\end{tabular}

${ }^{a}$ Size of a power plant operating at $80 \%$ capacity factor that would generate the amount of electricity saved. Actual capacity could be much higher if electricity savings are from a smaller fraction of the year. 


\section{RENEWABLE ENERGY ANALYSIS}

\subsection{REFERENCE ENERGY PRODUCTION}

Projected renewable energy use in the residential (Table 17) and commercial sectors (Table 18) in North Carolina come largely from wood used in heating, with some use of solar thermal and geothermal energy. A small amount of solar PV is added in later years. The modifications made in the high technology and best technology scenarios for those sectors actually lowers the renewable energy use slightly, as building heating and cooling requirements decline and technologies improve in their efficiency.

Table 17. NC residential renewable energy use (14.1\% of South Atlantic region)

\begin{tabular}{|lcccc|}
\hline \multicolumn{1}{rc}{ Renewables } & $\mathbf{2 0 0 0}$ & $\mathbf{2 0 1 0}$ & $\mathbf{2 0 2 0}$ & $\begin{array}{c}\text { Annual Growth } \\
\text { rate }\end{array}$ \\
\hline Wood & TBtu & TBtu & TBtu & $-0.2 \%$ \\
Solar Thermal & 10.01 & 9.75 & 9.69 & $2.1 \%$ \\
Geothermal & 1.29 & 1.62 & 1.95 & $4.4 \%$ \\
Non-grid PV & 0.20 & 0.32 & 0.48 & $21.7 \%$ \\
\hline \multicolumn{1}{|c}{ Delivered Energy } & 0.000 & 0.002 & 0.004 & $0.3 \%$ \\
\hline
\end{tabular}

Table 18. NC commercial renewable energy use (19.3\% of South Atlantic region)

\begin{tabular}{|lrrrr|}
\hline \multicolumn{1}{|c}{ Renewables } & $\mathbf{2 0 0 0}$ & $\mathbf{2 0 1 0}$ & $\mathbf{2 0 2 0}$ & $\begin{array}{c}\text { Annual Growth } \\
\text { Rate }\end{array}$ \\
\hline Biomass & TBtu & TBtu & TBtu & $0.0 \%$ \\
Solar Thermal & 4.0 & 4.0 & 4.0 & $1.7 \%$ \\
Non-grid PV & 0.2 & 0.2 & 0.3 & $29.0 \%$ \\
\hline \multicolumn{1}{|c}{ Delivered Energy } & 0.00 & 0.02 & 0.17 & $0.3 \%$ \\
\hline
\end{tabular}

Separately, NEMS calculates renewable energy use for electricity production. It models production by both utility-owned power plants and cogeneration of electricity by end-users (both industrial and commercial.) It further separates the end-user production between that which just provides electricity and combined heat and power production.

In the electricity market module, NEMS uses thirteen regions based on the electrical reliability councils across the country (Figure 16), rather than the census regions as in the residential and commercial sectors. North Carolina is located in the Southeastern Electric Reliability Council (SERC), along with South Carolina, Georgia, Alabama, Mississippi, Tennessee, and parts of Louisiana, Arkansas, Missouri, Florida, and Virginia. 
Figure 16. NEMS Electricity Market Module regions

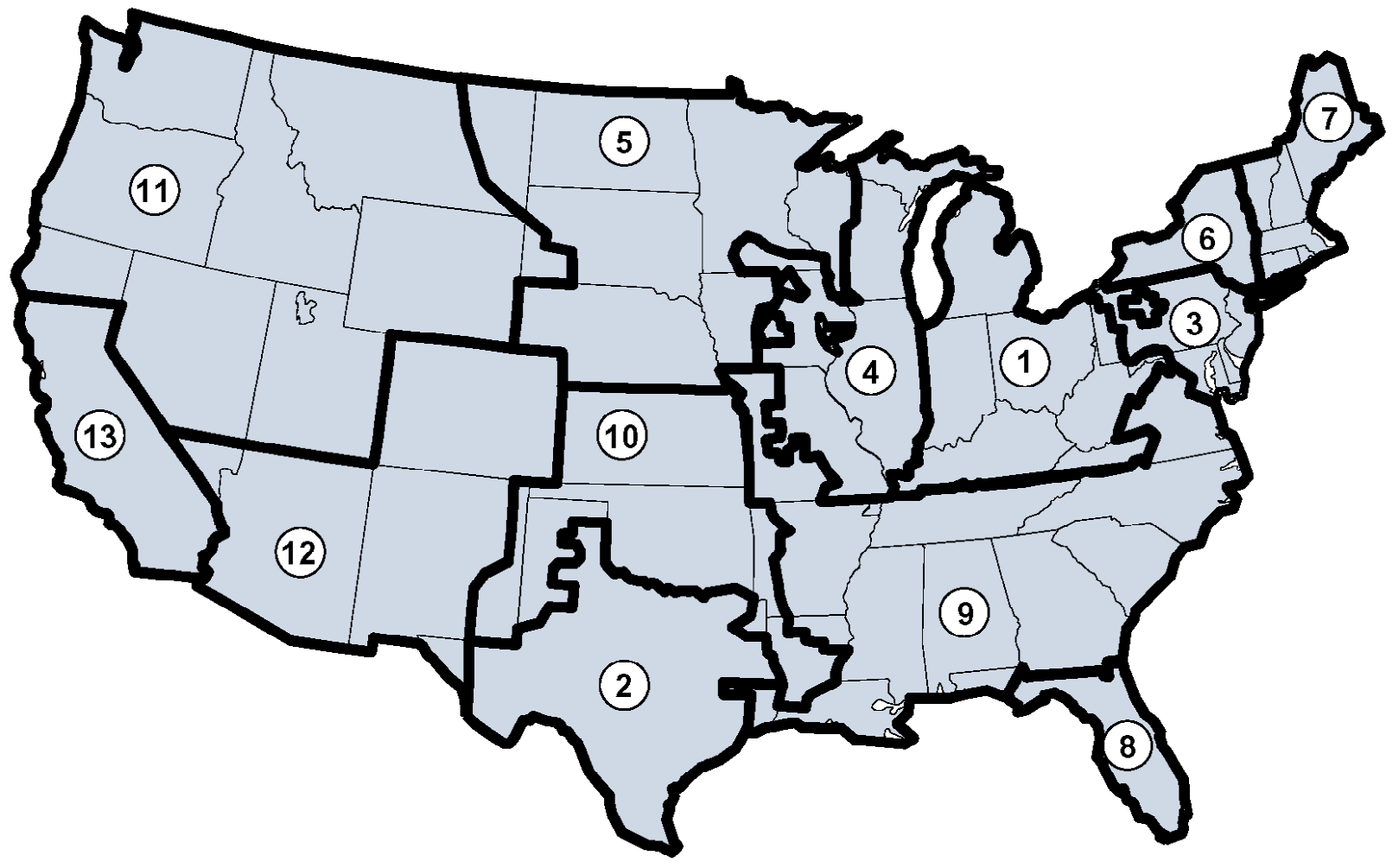

1 East Central Area Reliability Coordination Agreement

2 Electric Reliability Council of Texas

3 Mid-Atlantic Area Council

4 Mid-America Interconnected Network

5 Mid-Continent Area Power Pool

6 New York

7 New England
8 Florida Reliability Coordinating Council

9 Southeastern Electric Reliability Council 10 Southwest Power Pool

11 Northwest Power Pool

12 Rocky Mountain Power Area, Arizona, New Mexico, and Southern Nevada 13 California

The SEDS data used to calculate the ratio of North Carolina energy use to the South Atlantic region can also be applied to find the ratio of the state to the SERC region. However, the results will only be approximate because the SERC region does not strictly follow state boundaries. Furthermore, the SEDS data shows no use of renewable energy in the electric utility sector except hydropower. However, it does have a category for wood and waste in the industrial sector. North Carolina represents around 7\% of the total wood and waste use for the SERC region (a three-year average of $68 \mathrm{TBtu}$ compared to $943 \mathrm{TBtu}$ ). It also generates roughly 12\% of the region's hydro power.

Because renewable power availability will vary more between states than the energy use in the residential and commercial sector, it is inappropriate to use a simple percentage multiplier of 7\% on all renewable production in the SERC region to determine the North Carolina proportion. However, the results from NEMS for the SERC region as a whole should still provide some insight into the potential for renewable energy use in North Carolina. 
Total renewable energy use for electric generation in the SERC region from the Base scenario is shown in Table 19. Conventional, utility-owned hydropower makes up the bulk of the capacity over the entire period, but the scenario projects no growth in that source. Wood and other biomass make up the next largest source, both from combined heat \& power (CHP) usage (such as at pulp and paper manufacturers) and in generation-only facilities. Municipal solid waste (MSW) contributes some $320 \mathrm{MW}$ of power for the region.

The Base scenario shows large growth rates for PV and wind power in the region, though starting from very small bases. They reach 310 and 472 MW of power respectively by 2020 .

Table 19. SERC region renewable energy capacity in Base scenario, GW

\begin{tabular}{|lrrrr|}
\hline \multicolumn{1}{|c}{ Capacity Type } & $\mathbf{2 0 0 0}$ & $\mathbf{2 0 1 0}$ & $\mathbf{2 0 2 0}$ & \multicolumn{1}{c|}{$\mathbf{2 0 0 0 - 2 0 2 0}$} \\
\hline Utility Hydropower & 11.24 & 11.24 & 11.24 & $0.0 \%$ \\
Industry Hydro & 0.55 & 0.55 & 0.55 & $0.0 \%$ \\
Utility Municipal Solid Waste & 0.18 & 0.24 & 0.24 & $1.4 \%$ \\
Combined Heat \& Power - MSW & 0.14 & 0.14 & 0.14 & $0.0 \%$ \\
Utility - Wood and Other Biomass & 0.33 & 0.33 & 0.33 & $0.0 \%$ \\
CHP - Wood and Other Biomass & 2.20 & 2.94 & 3.88 & $2.9 \%$ \\
End-User Solar PV & 0.006 & 0.189 & 0.310 & $21.5 \%$ \\
Wind & 0.004 & 0.082 & 0.472 & $27.0 \%$ \\
\hline Total & 14.65 & 15.70 & 17.15 & $0.8 \%$ \\
\hline
\end{tabular}

\subsection{IMPROVEMENTS}

The High Renewable scenario in the AEO 2003 utilizes improved capital costs or efficiencies for the various renewable energy types as described in the quote below from the Assumptions to the Annual Energy Outlook 2003(EIA 2003b).

The High Renewables case examines the effect on energy supply of using cost and performance assumptions for non-hydro, non-landfill gas renewable energy technologies approximating published goals of the relevant program offices of the U.S. Department of Energy, Office of Energy Efficiency and Renewable Energy (DOE/EE). For electric power sector technologies, the High Renewables assumptions are designed to correspond to year 2020 cost and performance goals in the Renewable Energy Technology Characterizations document jointly published by the DOE/EE and the Electric Power Research Institute (EPRI 1997). These assumptions, summarized in Table 20, include:

- Biomass: For biomass in the high renewables case, capital costs are modified from reference case values such that they are similar to those in the EE/EPRI Technology Characterization costs for biomass gasification by 2025. In addition, biomass supplies are increased 10 percent across all price steps for the four types of biomass. Fixed operations and maintenance costs are reduced about 14 percent to be consistent with Technology Characterization costs. Biomass capacity factors are unchanged from the reference case.

- Photovoltaics (Central Station): For photovoltaics, EIA assumes reduced capital and operations and maintenance costs, corresponding to utility scale flat plate "Thin 
Film" technology in the EE/EPRI Technology Characterizations. Performance is assumed unchanged from the reference case.

- Wind: EIA assumes reduced capital and operations and maintenance costs, with increased performance (as measured by capacity factor and energy capture per swept rotor area) in all wind classes. The maximum allowable capacity factor is set to 49 percent, and the growth rate parameters are increased to allow the model to achieve capacity factor goals specified in the EE/EPRI Technology Characterizations.

Table 20. Renewable capital cost and efficiency parameters in Base and High Renewable scenarios

\begin{tabular}{|c|c|c|c|c|c|}
\hline \multirow[b]{2}{*}{$\begin{array}{l}\text { Technology/ } \\
\text { Decision Year }\end{array}$} & \multirow[b]{2}{*}{$\begin{array}{c}\text { Overnight } \\
\text { Costs in 2001 } \\
(\$ 2000 / \mathrm{kW}) \\
\end{array}$} & \multicolumn{2}{|c|}{ Total Overnight Costs ${ }^{1}$} & \multicolumn{2}{|c|}{$\begin{array}{l}\text { Best Available Capac- } \\
\text { ity Factors }\end{array}$} \\
\hline & & $\begin{array}{c}\text { Base } \\
(\$ 2000 / \mathrm{kW})\end{array}$ & $\begin{array}{l}\text { High Re- } \\
\text { newable } \\
(\$ 2000 / \mathrm{kW})\end{array}$ & Base (\%) & $\begin{array}{c}\text { High Re- } \\
\text { newable (\%) }\end{array}$ \\
\hline Biomass & 1,764 & & & & \\
\hline 2005 & & 1,718 & 1,669 & 80 & 80 \\
\hline 2010 & & 1,635 & 1,573 & 80 & 80 \\
\hline 2015 & & 1,547 & 1,461 & 80 & 80 \\
\hline 2020 & & 1,464 & 1,352 & 80 & 80 \\
\hline 2025 & & 1,265 & 1,272 & 80 & 80 \\
\hline MSW - Landfill Gas ${ }^{2}$ & 1,461 & & & & \\
\hline 2005 & & 1,451 & 1,451 & 90 & 90 \\
\hline 2010 & & 1,436 & 1,436 & 90 & 90 \\
\hline 2015 & & 1,420 & 1,420 & 90 & 90 \\
\hline 2020 & & 1,404 & 1,404 & 90 & 90 \\
\hline 2025 & & 1,388 & 1,388 & 90 & 90 \\
\hline Wind & 1,004 & & & & \\
\hline 2005 & & 997 & 984 & 40 & 42 \\
\hline 2010 & & 994 & 951 & 41 & 44 \\
\hline 2015 & & 992 & 919 & 42 & 46 \\
\hline 2020 & & 990 & 886 & 42 & 47 \\
\hline 2025 & & 989 & 853 & 42 & 48 \\
\hline Photovoltaic & 3,460 & & & & \\
\hline 2005 & & 2,733 & 2,260 & 30 & 30 \\
\hline 2010 & & 2,462 & 1,686 & 30 & 30 \\
\hline 2015 & & 2,346 & 1,466 & 30 & 30 \\
\hline 2020 & & 2,270 & 1,246 & 30 & 30 \\
\hline 2025 & & 2,219 & 1,142 & 30 & 30 \\
\hline
\end{tabular}

${ }^{1}$ Overnight capital cost (i.e. excluding interest charges), plus contingency factors and learning, excluding regional multipliers.

${ }^{2}$ Provided to show evolution of landfill gas costs through 2025; for landfill gas, assumptions in the high renewables case are unchanged from the reference case

Source: EIA 2003b 
These characterizations are based on technology improvements rather than specific programs that states such as North Carolina would run. However, they provide insight into the level of penetration that may be feasible for these technologies. State programs may indirectly lead to these cost reductions through facilitation of early adoption, thereby allowing the technologies to proceed down the learning curve to lower cost targets. Alternatively, state tax structures or incentives (such as North Carolina's tax credits) may subsidize certain technologies, directly lowering their cost.

\subsection{ENERGY PRODUCTION}

With the improvements established in the high renewable scenario, several technologies add to their growth over that in the Base scenario (Table 21 and Figure 17). The largest increase is in the use of wood and other biomass, either in dedicated electric plants or as CHP. Solar PV more than doubles its capacity to $683 \mathrm{MW}$, surpassing Wind as an electricity producer. Wind also increases its capacity by $140 \mathrm{MW}$ to equal $607 \mathrm{MW}$ by 2020 . Overall, renewable energy capacity increases by $1.82 \mathrm{GW}$ to $19 \mathrm{GW}$, an $11 \%$ increase over the base scenario. This amount represents $7.7 \%$ of total electrical capacity for the region.

Table 21. Growth in renewable energy use in the High Renewable scenario in the SERC region, $\mathbf{G W}$

\begin{tabular}{|c|c|c|c|c|c|}
\hline \multirow[t]{3}{*}{ Capacity Type } & \multicolumn{2}{|c|}{2010} & \multicolumn{3}{|c|}{2020} \\
\hline & \multirow{2}{*}{\multicolumn{2}{|c|}{$\begin{array}{c}\text { Increase } \\
\text { over } \\
\text { Base }\end{array}$}} & \multirow[b]{2}{*}{ GW } & \multicolumn{2}{|c|}{ Increase over Base } \\
\hline & & & & $\mathbf{G W}$ & $\%$ \\
\hline Utility Hydropower & 11.24 & 0.00 & 11.24 & 0.00 & $0 \%$ \\
\hline Industry Hydro & 0.55 & 0.00 & 0.55 & 0.00 & $0 \%$ \\
\hline Utility Municipal Solid Waste & 0.24 & 0.00 & 0.24 & 0.00 & $0 \%$ \\
\hline Combined Heat \& Power - MSW & 0.14 & 0.00 & 0.14 & 0.00 & $0 \%$ \\
\hline Utility - Wood and Other Biomass & 0.33 & 0.00 & 0.90 & 0.58 & $177 \%$ \\
\hline CHP - Wood and Other Biomass & 3.17 & 0.24 & 4.62 & 0.74 & $19 \%$ \\
\hline End-User Solar PV & 0.203 & 0.013 & 0.683 & 0.37 & $120 \%$ \\
\hline Wind & 0.099 & 0.017 & 0.607 & 0.14 & $29 \%$ \\
\hline Total & 15.97 & 0.267 & 18.97 & 1.82 & $11 \%$ \\
\hline
\end{tabular}

The total additional renewable generation in the high renewable scenario versus the base scenario in the SERC region in 2020 is $6.45 \mathrm{TWh}$. Using the industrial electricity rate of $4.1 \varnothing / \mathrm{kWh}$, this translates into $\$ 266$ million worth of power. If North Carolina represents $7 \%$ of this extra production, in line with its percentage of industrial renewables compared to the region in the SEDS database, this would represent \$19 million of additional renewable production for that year. However, as stated earlier, the actual amount of increase in North Carolina versus other states may be quite different from that value. 
Figure 17. SERC region renewable energy capacity growth in the High Renewable Scenario over Base scenario, GW

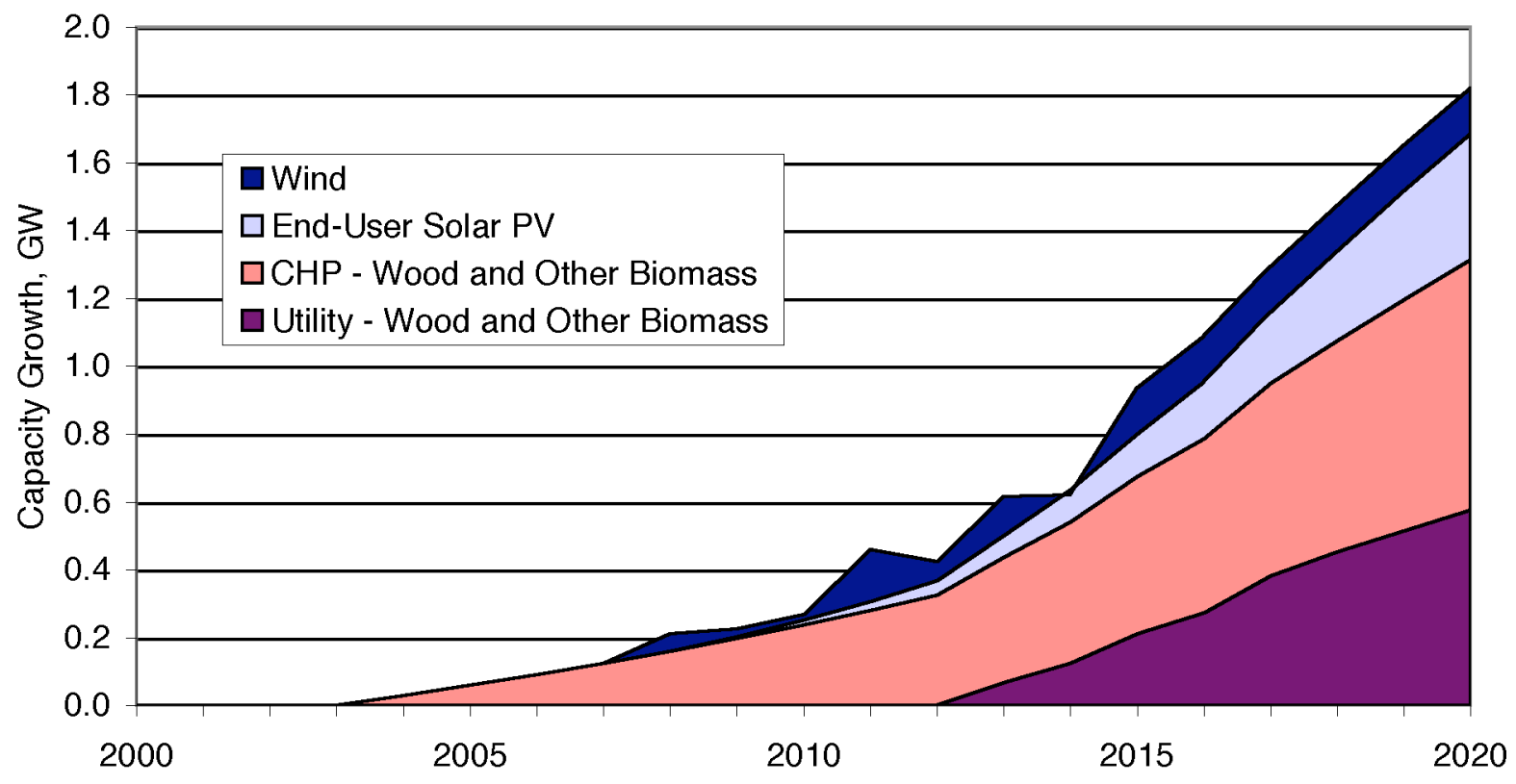




\section{SUMMARY}

The purpose of this study was to explore the potential for energy savings in the state of North Carolina. It concentrated on using economic simulation (the NEMS model) to determine the market potential for energy savings for the residential and commercial sectors and the potential penetration of renewable energy in all sectors.

The NEMS model is used by the Energy Information Administration to calculate twenty-five year projections of energy use for every region of the country. The results of the Annual Energy Outlook 2003 were used as the Base case. Five alternative scenarios were used to simulate energy savings policies, determine the maximum potential for savings, or identify the renewables most likely to penetrate the North Carolina market. Market-related programs were simulated by lowering the effective discount rates that end-users use when making decisions on equipment purchases. The values to use for these programs were based on the Moderate scenario assumptions from the DOE Clean Energy Futures study (IWG 2000). This scenario was based on analyses of a number of residential and commercial programs across the country. It assumed increased concern by society on energy efficiency but not to the point of fiscal policies such as taxes or direct subsidies.

Improved end-use equipment was made available under a second scenario to determine the potential for energy savings with equipment improvements. Changes in energy use would indicate that more efficient equipment would be able to penetrate the market, even with consumers deciding on purchases based on their current discount rates. A follow-on scenario combined both the advanced building technologies and lower discount rates to understand how these can work together to increase the amount of savings. Finally, a scenario was run that only allowed customers to purchase the most efficient equipment available. While this scenario shows large savings, cost was no object in the purchase decisions and so the results do not reflect real-world savings. However, the scenario does show the maximum amount of energy that foreseeably could be saved by each end-use.

The Residential sector reduced electricity demand by $3.4 \%$ by 2020 through the use of market incentives alone. This represented 2.3 TWh of electricity or $\$ 173$ million in savings in that year alone, at the residential electricity price of $7.6 \notin / \mathrm{kWh}$. The High Technology and High Technology plus Lowered Discount Rates scenarios saved North Carolina residents \$271 million and $\$ 463$ million annually by 2020 , respectively. These three scenarios saved the equivalent capacity of a $325 \mathrm{MW}, 508 \mathrm{MW}$, or $869 \mathrm{MW}$ power plant, respectively.

The Commercial sector's market potential for electrical energy savings was calculated to be $6.7 \%$ of its total expected electrical use by 2020, representing 3.4 TWh of power by 2020 . At the commercial sector price of $6.9 \notin / \mathrm{kWh}$ the savings represent $\$ 237$ million per year and the displacement of a $491 \mathrm{MW}$ power plant. Combining the lowered discount rate with high technology, annual savings reached $\$ 328$ million annually and the equivalent of a $680 \mathrm{MW}$ plant.

Renewable energy is used both for thermal energy within the residential and commercial sectors and for power generation. The NEMS base scenario shows renewable energy continuing to grow within the state and region. Conventional hydro power represents the largest renewable power 
source, followed by wood and other biomass. The Base scenario shows growth mainly in biomass use in combined heating and power applications, at $2.9 \%$ per year. Municipal solid waste (e.g., landfill gas) use also grows by $1.4 \%$ per year. Wind power and photovoltaic show large growth rates for the region, $>20 \%$ per year, but start from a very small base. By 2020 renewable power generation totals $17 \mathrm{GW}$ in the SERC region. (North Carolina will be $\sim 10 \%$ that amount.) If advanced renewable technologies are deployed, then another $1.8 \mathrm{GW}$ of renewable power may be built in the region, mainly wood and other biomass using CHP.

This study only examined some of the potential savings that may be possible. For example, lighting improvements in the residential sector, higher efficiency standards, and energy savings in the industrial sector were not examined. Programs to encourage the use of renewable energy were not explicitly analyzed beyond technology enhancements to lower costs or improve efficiency. Expansion of studies into these areas may be useful in the future. Also, the growth of miscellaneous other energy uses such as electronics makes these a significant fraction of future demands and may warrant further investigation. Energy savings programs specific to these uses (such as Energy Star) may be helpful in slowing their growth.

Overall, there is a good potential for saving over $6 \%$ of electricity use in North Carolina through a combination of market programs and technology advances, representing over $\$ 400$ million savings per year. Renewable energy growth could be accelerated through technology advancements or incentives to supply several hundred megawatts of additional power as well. With the recent rise in fossil energy costs, state residences and businesses have even greater incentive to save. Active state and utility programs should be able to achieve well over this amount, especially if applied to broader savings measures beyond just those studied here. 


\section{REFERENCES}

EIA (Energy Information Administration) 1999a, State Energy Data Report 1999, Consumption

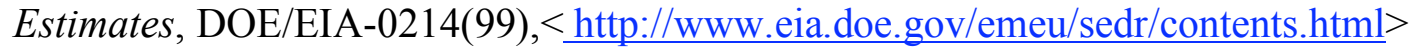

EIA 1999b, A Look at Residential Energy Consumption in 1997, DOE/EIA-632(97), U.S. Department of Energy, Washington, DC, November.

$<$ http://www.eia.doe.gov/emeu/recs/contents.html $>$

EIA 2001, Integrating Module of the National Energy Modeling System: Model Documentation 2002, DOE/EIA-M057(2002), U.S. Department of Energy, Washington, DC, December.

EIA 2002a, Model Documentation: Renewable Fuels Module of the National Energy Modeling System, DOE/EIA-M069(2002), U.S. Department of Energy, Washington, DC, February.

EIA 2002b, A Look at Commercial Buildings in 1999: Characteristics, Energy Consumption, and Energy Expenditures, DOE/EIA-625(9), U.S. Department of Energy, Washington, DC, November, $<$ http://www.eia.doe.gov/emeu/cbecs/>

EIA 2003a, Annual Energy Outlook 2003: With Projections to 2020, DOE/EIA-0383 (2003)

Washington, DC: U.S. Department of Energy, January.

EIA 2003b, Assumptions for the Annual Energy Outlook 2003, DOE/EIA-0554 (2003) Washington, DC: U.S. Department of Energy, January.

Electric Power Research Institute and U.S. Department of Energy, Office of Utility Technologies 1997, Renewable Energy Technology Characterizations, EPRI TR-109496, December.

http://www.eren.doe.gov/utilities/techchar.html

Interlaboratory Working Group, 2000, Scenarios for a Clean Energy Future (Oak Ridge, TN; Oak Ridge National Laboratory and Berkeley, CA; Lawrence Berkeley National Laboratory), ORNL/CON-476 and LBNL-44029, November.

http://www.ornl.gov/ORNL/Energy_Eff/CEF.htm

McElhaney, K. L., Jallouk, P. A., 1999, State-by-State Estimated Potential Energy Savings Achievable from Implementation of Efficiency Measures and Practices Identified by the DOE Motor Challenge Program (draft), Oak Ridge National Laboratory, January. 